Int. J. Dev. Biol. 62: 537-550 (2018)

https://doi.org/10.1387/ijdb.180042es

\title{
Rebuilding a planarian: from early signaling to final shape
}

\author{
FRANCESC CEBRIÀ, TERESA ADELL and EMILI SALÓ* \\ Departament de Genètica, Microbiologia i Estadística, Facultat de Biologia, Universitat de Barcelona and Institut de \\ Biomedicina de la Universitat de Barcelona (IBUB), Universitat de Barcelona, Barcelona, Catalunya, Spain
}

\begin{abstract}
Why some animals can regenerate and others not has fascinated biologists since the first examples of regeneration were reported. Although many animal phyla include species with some regenerative ability, mainly restricted to particular cell types or tissues, there are some other species capable of regenerating complex structures, such as the vertebrate limb and heart. More remarkably, there are some examples of animals that can regenerate the whole body from a tiny piece of them. Understanding how regeneration is triggered and achieved in these animals is fundamental not only to understand this fascinating primary biological question, but also because of its implications for the field of regenerative medicine. Here, we discuss one of the models with higher regenerative capabilities: the freshwater planarians. Two key features make planarians an attractive model to study regeneration: the presence of adult pluripotent stem cells and the permanent activation of the morphogenetic mechanisms that instruct cell fate. Here, we revise our current knowledge of key events that lead to successful regeneration including: how heterogeneous is the stem cell population; what are the immediate changes at the gene level after amputation and what triggers the regenerative response; how is axial polarity re-established; how do the different cell types differentiate from lineage-committed progenitors and how is size and organ proportionality controlled. Finally, we point out some open questions that the field needs to address in the near future.
\end{abstract}

KEY WORDS: planarian, regeneration, neoblast, signaling, morphogenesis, cell differentiation

\section{Introduction}

The majority of model organisms with regenerative capabilities can only regenerate certain organs or extremities. However, a select few, including Hydra, planarians, and starfish can regenerate the entire organism from small portions thereof. Planarians can regenerate from a wide array of body fragments, and can arguably regenerate faster and more comprehensively than any other bilaterian. Freshwater planarians are dorsoventrally flattened, softbodied, free-living members of the phylum Platyhelminthes. They are acoelomate and triploblastic, and lack circulatory, respiratory, or skeletal structures. Their striking regenerative ability has attracted the interest of scientists for centuries, and has led to their use as a classical model system of regeneration (Saló and Baguñà, 2002; Reddien and Sánchez-Alvarado;2004, Saló, 2006). In other models such as amphibians and zebrafish regeneration is partially driven by cell dedifferentiation (Tanaka, 2016). By contrast, regeneration in planarians is based upon two key biological properties: 1) the presence in adult organisms of an abundant population of pluripotent stem cells; and 2) the continuous activity and coordination of cell-to-cell communication signaling pathways. Moreover, intact planarians display a high level of plasticity; their morphogenetic pathways are always "on", enabling continuous growing and degrowing depending on environmental conditions, while always retaining proper body proportions (Saló, 2006). With advances in the development of molecular and genomic methodologies, planarians have become the reference organisms for the study of regeneration and homeostatic cell turnover. RNA interference (RNAi), administered by injection, feeding or soaking, shows high penetrance in planarians, enabling effectively interference with gene function. This methodology can be used to alter the expression of several genes simultaneously. Indeed, RNAi loss-of-function studies have led to the discovery of many cellular and molecular processes involved in regulating planarian regeneration.

\section{What drives the regenerative response after sectioning?}

After injury in planarians, wound healing is mediated by local muscle contraction, which put into contact the existing dorsal and

Abbreviations used in this paper: ROS, reactive oxygen species.

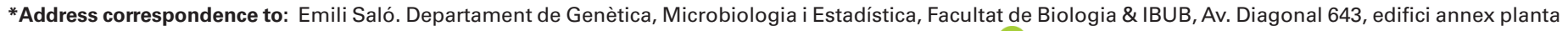
1, 08028 Barcelona, Catalunya, Spain. Tel. +34 934035977. Fax +34 934034420. E-mail: esalo@ ub.edu - (iD) https://orcid.org/0000-0001-5460-9223
} 

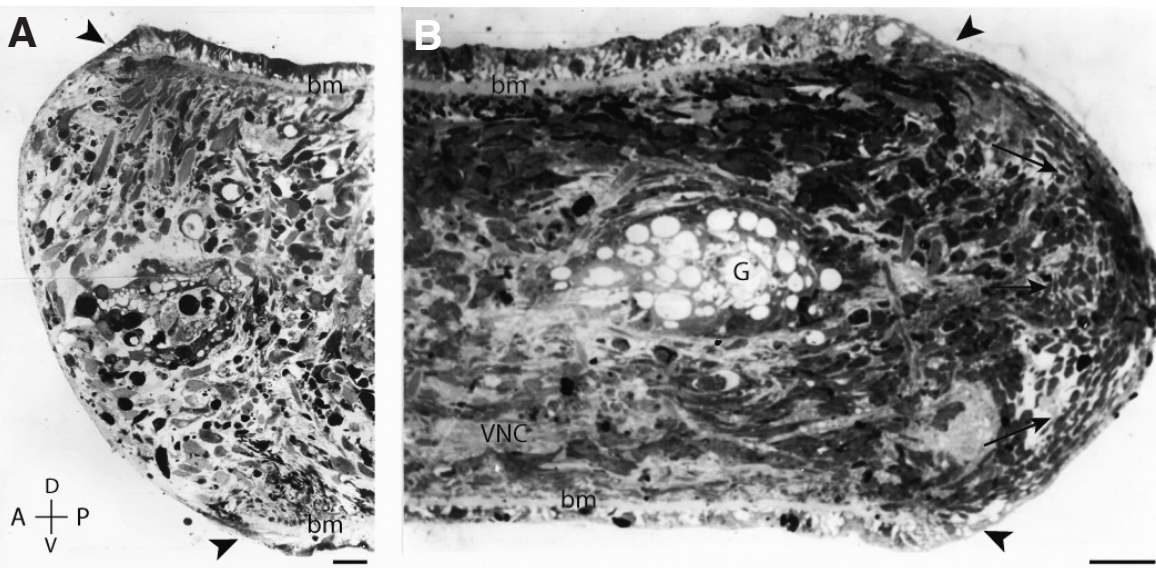

Fig. 1. Light micrographs of planarian sagittal sections stained with borax-azur II and methylene blue. (A) Tail fragment 30 minutes after cutting. A thinly stretched wound epithelium covers the entire wound area. The end of the basal membrane of the existing epidermis indicates the cut level (arrowheads). (B) Head fragment 24 hours after cutting. Arrowheads indicates the cut level. The wound epithelium is maintained and a dense aggregation of neoblasts, initiating blastema formation (arrows), is visible beneath the wound. bm, basal membrane; $A$, anterior; $P$, posterior; $D$, dorsal; V, ventral; G, gut; VNC, ventral nerve cord. Scale bars: 50 um.

ventral epidermis. Shortly after muscle contraction, muscle relaxation induces stretching of the existing epidermis, which closes the wound with a thin epidermal film (Fig. 1) (Chandebois, 1980). Direct contact between the healing epidermis and the mesenchyme facilitates epithelial-mesenchymal interactions, which trigger the early gene response. Once the epithelium is regenerated a new basal membrane is produced. All injuries (with or without tissue loss) trigger an early, generic gene response, affecting mainly the epidermis, muscle, and neoblast population (Wenemoser et al., 2012). A first wave of gene upregulation occurs in differentiated cells, and includes two subgroups of early genes that are transiently activated within 30 minutes of injury until 6 or 12 hours after respectively. These genes are activated in the vicinity of the wound in a translation-independent manner, and are predominantly transcription and signaling factors (e.g., jun-1, fos-1, egrl-1, egr-2,-3,-4, MAP3K-1) (dashed blue line, Fig. 2). In addition, a group of genes encoding extracellular remodeling matrix proteins and signaling components is expressed ubiquitously in the existing epidermis (blue line, Fig. 2). The role of ECM during regeneration in cell migration and anoikis was described (Isolani et al., 2013). In addition, recent studies have demonstrated that changes in the extracellular matrix (ECM) during regeneration are involved in both the assembly of tissues from differentiating progenitor cells (Bonar and Petersen, 2017; Seebeck et al., 2017) and in neoblast migration (Abnave et al., 2017). In the mesenchyme close to the wound site, a second wave of translation-dependent gene expression is initiated during the first 6 hours post-injury. The genes involved, which include wnt-1, nlg1, inhibin-1, and follistatin, belong to different pathways required for patterning (Sandman etal., 2011, Wenemoser etal., 2012, Wurtzel et al., 2015). This second wave occurs in cases involving tissue loss, and specific gene expression depends on the missing region (Injury specific response, green line, Fig. 2). A parallel wave of wound-induced gene expression in neoblasts includes transcription factors, chromatin remodeling proteins, histone methyltransferases, and cell cycle factors (dashed green line, Fig.2). Finally, differentiated tissue markers are expressed 72 hours after injury (red line, Fig. 2) (Wenemoser et al., 2012; Wurtzel et al., 2015). In summary, injury triggers the activation of general injury-response genes, followed by injury type-dependent gene expression, which enables acquisition of the appropriate tissue identity and pattern, depending on the missing tissue. Finally, the expression of cell-differentiation genes promotes tissue and organ differentiation, restoring functionality (Fig. 2). A recent study has shown the importance of ERK signaling in initiating regeneration in planarians (Owlarn et al., 2018). Importantly, in this study it has been shown that the generic wound response to any kind of injury is necessary to induce regeneration in a missing-tissue context.

Planarian regeneration is dependent on the presence of pluripo-

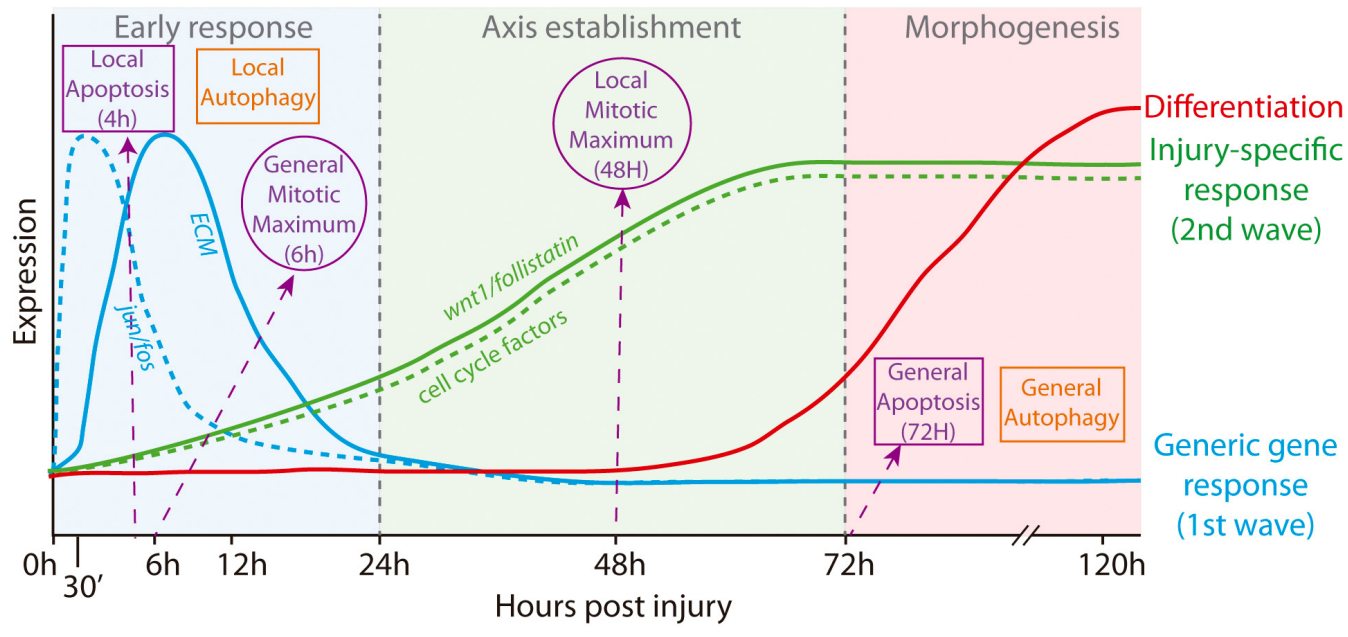

Fig. 2. Summary of the main events that regulate planarian regeneration at the genetic and cellular levels. Any type of injury, regardless of whether tissue is lost or not, triggers a generic rapid and transient gene response lblue box and continuous and dashed blue lines). During this early response, local increases in apoptosis and autophagy in the regions close to the wound and a general activation of mitosis are observed. In cases involving tissue loss, the decline of the early response is followed by the activation of a new set of genes involved in injury-specific responses (green box and continuous

and dashed green lines). The genes activated are related to axis respecification and patterning. During this period mitotic activity in regions close to the wound peaks, resulting in a significant increase in the amount of new blastemal tissue. In the final stage, which is characterized by differentiation and morphogenesis (red box and red line), existing tissue is remodeled in accordance with the new body proportions via general apoptosis and autophagy. 
A

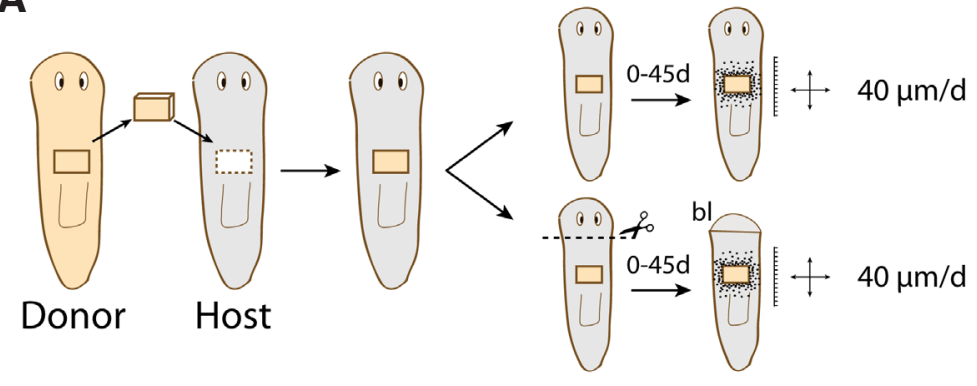

B

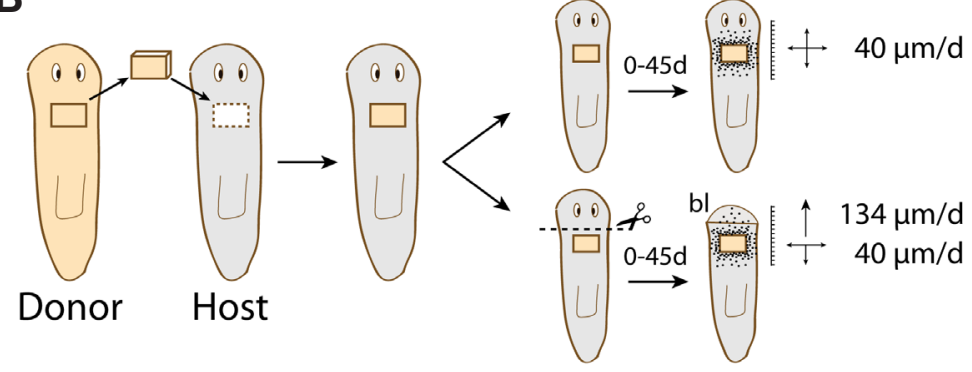

Fig. 3. Grafting method used to analyze cell migration. When a fragment of S. mediterranea sexual strain is grafted to a S. mediterranea asexual strain, the origin of cells can be traced using the chromosomal heteromorphic marker of the asexual strain cells. These experiments revealed that in intact animals (A-B) and amputated far from the transplant no oriented migration of cells is observed (dots) (A), showing an non-oriented migration/spreading of $40 \mu \mathrm{m} /$ day. Interestingly, this migration is preferentially oriented towards the wound when the graft is close to the wound, showing an estimated speed of $134 \mu \mathrm{m} /$ day (B). bl, blastema.

tent adult stem cells, a unique cell type whose proliferative ability is activated in response to injury. Neoblasts exhibit a coordinated bimodal mitotic response, with a body-wide peak observed 6 hours post-injury, consisting mainly of G2 neoblasts, followed by a second peak around the wound region (Fig. 2) (Saló and Baguñà, 1984). This second local peak occurs only when the injury results in tissue loss; simple poking or small incisions induce only the first general wave of early mitotic activation (Wenemoser and Reddien, 2010). The second local wave of neoblast mitosis occurs in the existing tissue and produces new undifferentiated tissue, known as blastema. Although the blastema continues to grow, the mitotic activity remains mainly localized within the pre-existing tissue close to the wound (an area of $\sim 500 \mu \mathrm{m}$ in diameter), an area known as the postblastema (Saló and Baguñà, 1989). The blastema therefore grows from its base through the entry and accumulation of non-dividing neoblasts produced in the postblastema (Saló and Baguñà, 1984; Wenemoser and Reddien, 2010). Some studies have proposed that the accumulation of mitotic neoblasts in the postblastema is a local process. Grafting experiments demonstrate that an amputation triggers the accumulation of mitotic cells at the wound region and that the origin of those cells is not farther than $500 \mu \mathrm{m}$ from the wound approximately (Fig. 3) (Saló and Baguñà, $1985,1989)$. Long distance migration has only been observed in experiments of partial irradiation (Dubois, 1949; Guedelhoefer and Sánchez-Alvarado, 2012). Thus, if a planarian is partially irradiated in the anterior region and then the head is amputated, neoblasts from the non-irradiated tail region migrate towards the anterior wound in few days. Interestingly, neoblasts only invade the irradiated tissue after amputation, but never in homeostatic conditions, indicating that wounding triggers the migratory response (Guedelhoefer and Sánchez-Alvarado, 2012). More recently, it has been suggested that the cellular migration would include not only stem cells but also committed cells (Abnave et al., 2017).

Planarian regeneration is a global process, involving the production of new tissue (the blastema) at the amputation planes, as well as the remodeling of existing fragments to adjust to the organism's new proportions. The latter process is dependent on cell death mediated by apoptosis and autophagy. During regeneration, apoptosis occurs in two waves. The first peaks a maximum at 4 hours post-injury and is local, affecting the region close to the wound. The second peaks a maximum at 3 days post-injury and is general in nature (affecting the entire body) (Fig. 2) (Pelleteri et al., 2010). Autophagy is also activated very early during regeneration, with activity observed 1 day post-amputation localized mainly in the postblastema region, spreading gradually to all existing tissues as remodeling processes occur (Fig. 2). However, additional activation of autophagy occurs in the reproductive system, testis, and ovaries at 1 day post-amputation (González-Estévez et al., 2007).

Recent studies in animal models indicate that cell death is a pre-requisite to trigger the regenerative response (Bergantiños et al., 2010; Vriz et al., 2014). However, in planarians it remains unclear whether apoptosis is required for regeneration; no studies have examined the effects of directly inhibiting apoptosis during regeneration. What it is known is that in planarians conserved JNK expression is required to induce the early apoptotic response 4 hours after injury (Almuedo-Castillo et al., 2014). Importantly, inhibition of JNK in planarians not only inhibits the early apoptotic response but also unblocks the G2-M checkpoint of neoblasts entering mitosis, and prevents the activation of early-response genes. JNK therefore serves as a hub, translating wound signals into apoptotic cell death, controlled stem cell proliferation, and differentiation during regeneration (Almuedo-Castillo et al., 2014). Also, there is evidences that Akt signaling mediates the spatial distribution of cell death during tissue repair (Peiris et al., 2016). Although the molecular and cellular mechanisms upstream remain unclear, cell death is commonly triggered by the activation of reactive oxygen species (ROS), mainly through MAPK or JNK signaling (Vriz et al., 2014).

\section{Reactive oxygen species and planarian regeneration}

In recent years, ROS have emerged as key players in the initiation of the regenerative program in a variety of models. ROS include molecules such as $\mathrm{O}_{2}^{-}$, peroxide $\left(\mathrm{H}_{2} \mathrm{O}_{2}\right)$, and hydroxyl radicals $\left(\mathrm{OH}^{-}\right)$, which are produced from oxygen as by-products of aerobic metabolism or enzymatic production and are implicated in multiple pathologies including cancer, aging, and neurological dysfunction. However, ROS also participate in cell regulation and signaling in development, immunology, wound healing, and angiogenesis (Alfadda and Sallam, 2012; Hernández-Garcia et al., 2010). Remarkably, ROS signaling is required for regeneration in a variety of models from Drosophila to newts, in which its blockade results in defective impaired regeneration. During Xenopustadpole tail regeneration, sustained ROS production is necessary for cell 
proliferation and activation of the Wnt/ $\beta$-catenin pathway (Love et al., 2013). Fin regeneration in zebrafish also requires the production of ROS, which then activate apoptosis and the JNK pathway to trigger the cell proliferation necessary to form the blastema (Gauron et al., 2013). ROS production also stimulates the proliferation of ependymiglia cells during regeneration of midbrain dopamine neurons in newts (Hameed et al., 2015). Finally, in Drosophila imaginal discs, ROS produced by dying cells activate JNK and p38 in the surrounding living cells, triggering a regenerative response (Santabárbara-Ruiz et al., 2015).

In planarians, however, although ROS inhibition also blocks regeneration (Pirotte et al., 2015) it is unknown whether it is required to initiate it. After amputation, a rapid burst of ROS production occurs in the wound region. The use of chemical inhibitors of ROS production such as DPI (diphenyleneiodonium chloride) and APO (apocynin) results in a marked reduction in blastema growth during regeneration. Interestingly, in contrast to the reported proproliferative role of ROS in other models, these defects in planarians do not appear to be due to a reduction in either cell proliferation or neoblast number. However, ROS inhibition clearly affects cell differentiation, inhibiting CNS regeneration and significantly reducing numbers of different neuronal cell types and epidermal progenitors (Pirotte et al., 2015). Future studies in planarians will need to identify the sources of ROS after amputation, as well as the downstream signaling pathways they affect. In other models, ROS action has been linked to MAKP signaling. The EGFR/ERK pathway, which plays an important role in cell differentiation during planarian regeneration (Fraguas et al., 2011, 2017; Tasaki et al., 2011), may also constitute a necessary target of ROS to ensure successful regeneration

\section{Axial establishment}

Successful and functional regeneration requires triggering of a wound response, to stimulate the generation of new cells, and activation of the signals that assign the correct fate to newly generated tissue. Thus, if a tail is amputated, the blastema cells must acquire posterior, and not anterior, identity. This process is particularly complex in planarians, which are capable of regenerating any missing region, regardless of the position or the size of the amputated portion. The molecular mechanisms that confer positional identity to the new blastema cells in planarians have been extensively studied over the last 10 years (Owlarn and Bartscherer, 2016; Almuedo-Castillo et al., 2012; Reddien, 2011; Molina et al., 2011). To stimulate regeneration, a signaling center is formed in the blastema very soon after amputation (Vogg et al., 2016). Depending on the position of the wound, the signaling center acquires an anterior $(A)$ or a posterior $(P)$ instructive activity. Thus, when the missing portion is anterior, the signaling center provides the signals required to properly regenerate a brain and all missing structures with the correct orientation and position with respect to the existing tissue. Similarly specialized signals are generated when the missing portion is posterior. These signaling centers, also known in planarians as poles (A or $\mathrm{P}$ ), consist of a cluster of muscle cells located at the tip of the blastema from early regenerative stages (12-24 h), which appearance requires proliferation and differentiation of preexistent stem cells (Petersen and Reddien 2009). The molecular signatures of the $A$ and $P$ poles have been partially deciphered. The A pole expresses notum (a Wnt inhibitor) and follistatin, as well as the transcription factors fox $D$ and $z i c-1$, which are required for the specialization of neoblasts into A pole progenitors (Petersen and Reddien, 2009; Vasquez-Doorman and Petersen, 2014; Scimone et al., 2014a; Roberts-Galbraith and Newmark, 2013; Gavino et al., 2013; Vogg et al., 2014; Oderberg et al., 2017; Owlarn and Bartscherer, 2016). The P pole expresses wnt1 and follistatin(Adell et al., 2009; Gavino et al., 2013; Petersen and Reddien, 2009). Several studies have shown that the key elements required for the formation of the A versus the $\mathrm{P}$ pole are notum and wnt-1, since RNAi of notum induces regeneration of a tail instead of a head, and RNAi of wnt 1 induces regeneration of a head instead of a tail (Adell et al., 2009; Petersen and Reddien, 2009; Petersen and Reddien, 2011) (Fig. 4). However, the results of a recent transcriptomic study suggest that the decisive determinant of AP fate is notum, which is the only element differentially regulated in $A$ and $P$ early blastemas (Wurtzel et al., 2015). This finding is of particular significance, given that in other organisms the main role of notum is to inhibit Wnt function. Interestingly, the expression of both secreted elements, notum and wnt 1 , begins as early as 6 hours post-amputation as a dotted pattern in muscle cells of any wound, and is not restricted to their ultimate location at the $A$ and $P$ poles, respectively, until 24 to 48 hours later (Petersen and Reddien, 2009; Petersen and Reddien, 2011; Sureda-Gómez et al., 2015). This dotted early expression pattern of both genes appears to be independent of proliferation, whereas their expression at the poles requires the proliferation of neoblasts. At which specific stages do notum and wnt1 specify the A versus the $P$ fate? It is assumed that this decision is made very early during regeneration. However, the lack of suitable tools to study gene function at specific times and locations has hindered researcher's efforts to answer to this question. The available data suggest that the $A$ and $P$ poles, once formed, have a role in the patterning and growth of the regenerating tissues, but that the decision to assign an $\mathrm{A}$ or $\mathrm{P}$ identity is taken earlier. For instance, inhibition of $p b x$, which blocks the formation of both $A$ and $P$ poles but does not affect the early expression of notum or wnt1, gives rise to planarians that display correct polarity but regenerate small blastemas (Chen et al., 2013; Blassberg et al., 2013) (Fig. 4). In fact, the $A$ and $P$ signaling centers of planarians share several properties with embryonic signaling centers such as the Spemann-Mangold organizer of amphibians and the zone of polarizing activity (ZPA) of vertebrate limbs (Reversade and De Robertis, 2005; Harfe, 2011). These centers may therefore be essential for proper tissue growth, in addition to providing patterning cues. In support of this view, silencing of $p b x$, as well as other elements involved in the formation of the A or $\mathrm{P}$ planarian poles, results in a no-tail or no-head phenotype instead of a head-to-tail or a tail-to-head transformation, illustrating the requirement of the poles for tissue growth (Petersen and Reddien, 2009; Rink et al., 2009; Petersen and Reddien, 2011; Sureda-Gómez et al., 2015; Adell et al., 2009; Hayashi et al., 2011; Vasquez-Doorman and Petersen, 2014; Scimone et al., 2014; Vogg et al., 2014).

Interestingly, in the no-tail and no-head phenotypes generated when the poles cannot be organized, the mediolateral $(\mathrm{ML})$ organization of A or $\mathrm{P}$ structures is lost. Thus, if a small brain is formed, it will lack the anterior commissure, while in posterior regeneration the two digestive branches and ventral nerve cords (VNCs) fuse and close to form a circle. These phenotypes suggest that the formation of the poles is required to pattern the new regenerating tissue relative to all body axes (AP, dorsoventral/DV and ML. In 
agreement, a recent study by the Reddien group proposes that the location at which the A pole forms is dependent upon the axial coordinates of the pre-existing tissue (i.e., the pre-existing AP axis, pre-existing DV plane, and the pre-existing midline (Oderberg et al., 2017). Thus, the A signaling center is formed at the intersection between the pre-existing DV plane and the midline. Using the positional information of the pre-existing tissue, any kind of wound can be correctly patterned and integrated into the pre-existing tissue. Another study by the same group demonstrated that axial coordinates do exist in adult intact planarians, and provide positional identity to adult planarian cells, including neoblasts (Witchley et al., 2013). These axial coordinates are provided by the so-called positional control genes (PCGs). PCGs are secreted elements (typically morphogens) expressed in muscle cells that surround the planarian body. The PCGs that have been functionally studied specify the 3 planarian body axes: the "posterior Wnts", which are expressed in a nested pattern along the AP axis and are responsible for its specification; BMP and its inhibitors, which are differentially expressed along the DV axis and are responsible for its specification; and Slit and Wnt5, which are responsible for the positioning of tissues with respect to the midline.

Thus, correct patterning and growth of regenerating blastemas depends on the organization of signaling centers in the A or $\mathrm{P}$ poles of the wound, formed at the intersection between the pre-existing
DV plane and the midline. In this sense, the requirements of adult planarians, which use pre-existing tissue as a reference point, differ to those of an embryo, which must specify all structures de novo. Planarians use this mechanism to ensure correct tissue specification and integration after any kind of injury. But how are the axial coordinates provided by the PCGs maintained in an organism that continuously adjusts its size, reproduces by fission, and can regenerate from any tiny fragment? Answering this question has been the recent focus of several research groups. It is now known that a gradient of $\beta$-catenin activity, which is regulated by a morphogenetic gradient of "posterior Wnts", patterns gene expression along the planarian AP axis (Iglesias et al., 2008; Petersen and Reddien, 2008; Gurley et al., 2008; Adell et al., 2010; Sureda-Gómez et al., 2016). The findings of a recent mathematical modeling study suggest that this gradient occurs autonomously in the tail and that it takes part of a self-organizing patterning system that patterns the AP axis during homeostasis and regeneration (Stückemann et al., 2017). This self-organizing system would require functional antagonism between the tail Wnt gradient and an as-yet-unidentified head-patterning system.

It was proposed that a FGF-like signal might function as a brain activator in planarians since inhibition of noudarake (ndk, a FGF receptor-like) produces an expansion of the neural tissues (Cebria et al., 2002a). However, functional studies demonstrate that $n d k$,

A
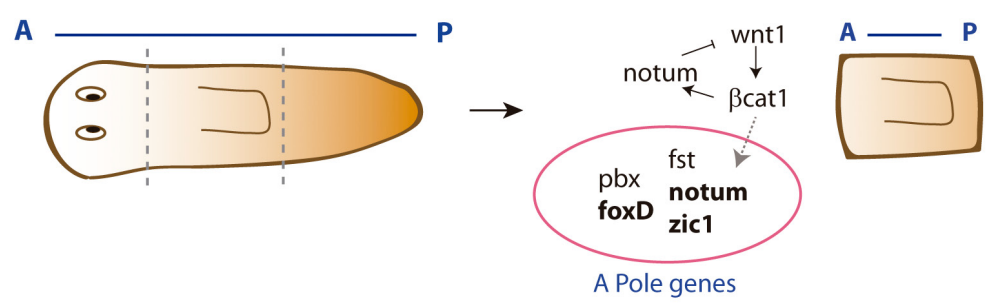

B
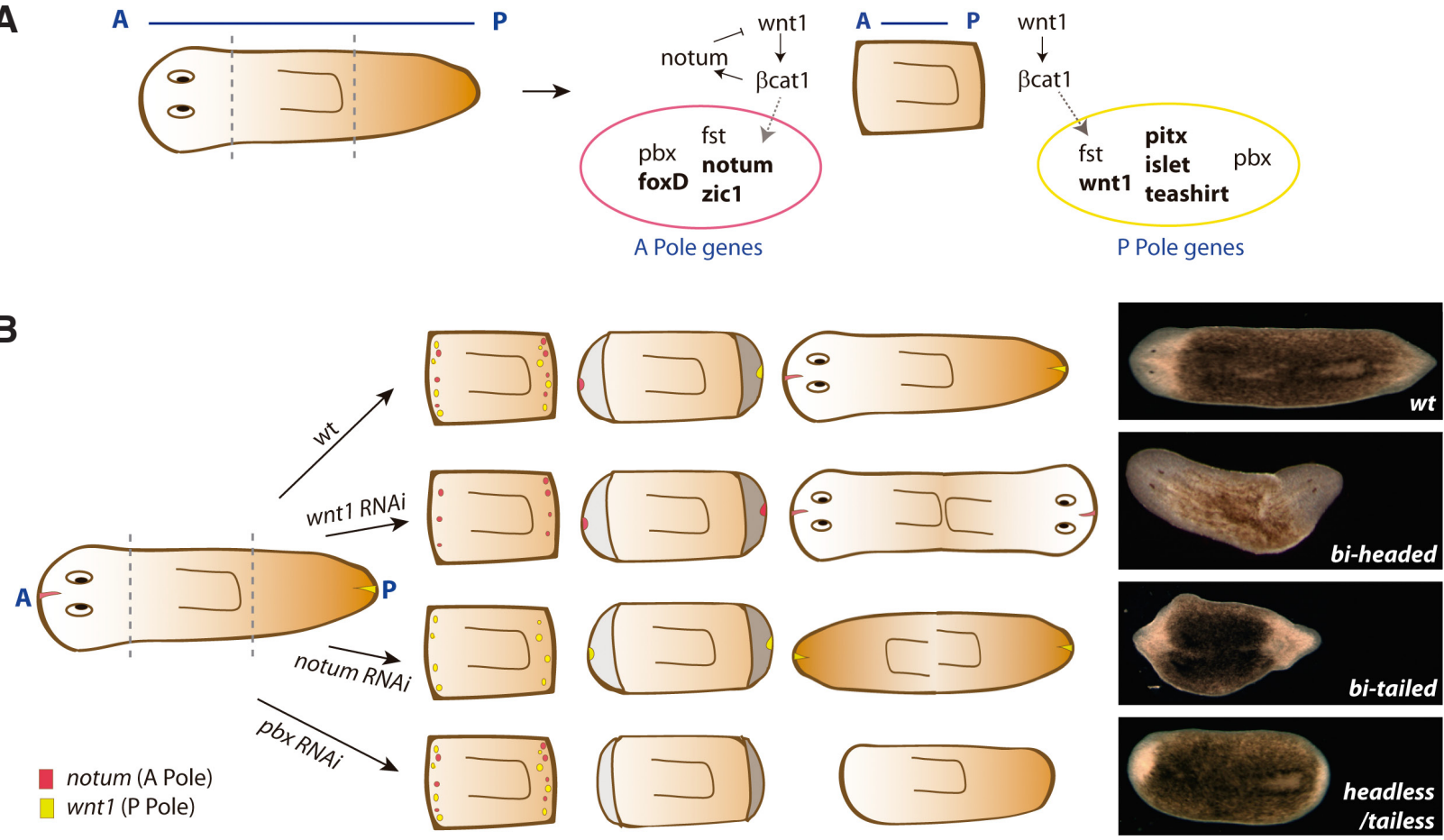

Fig. 4. Axial specification during planarian regeneration. (A) Schematic representation of the genes required for the specification of the $A$ and the $P$ poles. In the $A$ facing wound, the early expression of notum inhibits the early activity of wnt 1 and $\beta$ catenin 1 , allowing the expression of the $A$ Pole specific genes (foxD, zic1, notum). In the $P$ facing wound, notum is not expressed and the early wnt1 can activate the expression of the $P$ Pole genes (wnt1, pitx, islet, teashirt), through $\beta$ catenin1. The hierarquichal relationship between the $A$ and the $P$ pole genes is still not well resolved. $\beta$ catenin1 is also expressed in the A pole, where it could activate the expression of its own inhibitor, notum (Petersen and Reddien 2011; Sureda-Gómez et al., 2016). pbx and follistatin are required for the specification of both poles. (B) Schematic representation of the impact of wnt1, notum and pbx inhibition during the regeneration of the $A$ and $P$ poles. The final phenotype is shown. Inhibition of wnt1 produces the regeneration of an $A$ pole in $P$ (leading to bi-headed planarians), inhibition of notum produces the regeneration of a $P$ pole in A (leading to bi-tailed planarians), and inhibition of pbx impairs the regeneration of both poles (leading to animals that are not able to regenerate the missing tissues). Some images courtesy by Miquel Sureda-Gómez and Eudald Pascual. 
$w n t A$ and $f z 5 / 8-4$ are required to restrict the expansion of the head domain towards $P$, but they would not specify Aidentity (Adell et al., 2009; Hill and Petersen, 2015; Scimone et al., 2016). Recently, two groups of researchers identified new genes that are expressed in an overlapping manner along the body of planarians and provide positional information to cells (Lander et al., 2016; Scimone et al., 2016). Both studies corroborate the role of Wnt and FGF signals in the specification axial identities. They demonstrate that $n d l-3$ (a second FGF-like receptor), expressed in the prepharyngeal region, is required to restrict trunk identity, since its inhibition generates ectopic pharynges and mouths. The same phenotype is observed after inhibition of wnt11-2 (also called wntP-2 or wnt4-b) (Sureda-Gómez et al., 2015). Although the signals that specify the A signaling center need further clarification, together these findings suggest that in planarians the Wnt and FGF pathways coordinate positional identity along the planarian body axis. The restoration of regional identity during regeneration would depend upon the interpretation of those signals.

Interestingly, several studies demonstrate that the formation of the correct signalling center in regenerating blastemas also depends on a pre-existent polarity of the nervous system and on membrane voltage signalling pathways. Thus, H,K-ATPase-mediated membrane voltage and gap junction-dependent signals control head-versus-tail identity during planarian regeneration (Beane et al., 2011, Oviedo et al., 2010). It could be that bioelectric signals underlie the long-range information that specifies the activity of morphogens in the correct location (Lobo et al., 2012).

\section{Stem cell differentiation and morphogenesis}

Neoblasts are a population of heterogeneous cells that includes truly pluripotent stem cells as well as lineage-committed progenitors that give rise to the different specific mature tissues (Scimone et al., 2014b; van Wolfswinkel et al., 2014; Wagner et al., 2011; Zhu and Pearson, 2016). These progenitor populations are characterized by the co-expression of Smedwi-1, a neoblast marker, and transcription factors specific for the different cell lineages whose RNAi silencing inhibits the differentiation of specific cell types, suggesting that their co-expression with Smedwi-1 is characteristic of committed cell progenitors still capable of proliferating. How these committed progenitors are specified from pluripotent neoblasts remains to be elucidated. A homologue of the MEX3 RNA-binding protein is proposed to play a general role in cell differentiation, since silencing of its expression results in expansion of the stem cell compartment in parallel with a decrease in the number of lineage-restricted progenitors (Zhu et al., 2015). On the other hand the CCR4-NOT complex, which is involved in the regulation of mRNA degradation through deadenylation, promotes neoblast differentiation through the regulation of stem cell mRNA (Solana et al., 2013). Silencing of Smed-not1, a central scaffolding protein of the complex, inhibits regeneration, probably by blocking cell differentiation, as suggested by the specific accumulation of key neoblast markers exclusively in neoblasts, which would account for their failure to differentiate into different cell lineages (Solana et al., 2013). Finally, it has also been reported that a PIWI homologue inherited from pluripotent neoblasts may be necessary for transposon silencing and normal differentiation of those descendent cells (Shibata et al., 2016). However, the exact cues that cause pluripotent neoblasts to activate the genetic programs that convert them into epidermal, gut, or neural progenitors, among other cell types, remain poorly understood. These cues may be both intrinsic and extrinsic. A recent study proposed that the complex body-wall musculature may serve as the source of positional information (Witchley et al., 2013). In the case of planarian eyes, in intact planarians the progenitors of the new photoreceptor and pigment cells are found exclusively in the head region posterior to the eyes (Lapan and Reddien, 2011, 2012). Those progenitors are thought to be responsible for the normal turnover of eye cells. The fact that those progenitors are only found around the eyes suggests that extrinsic cues may regulate their specification from pluripotent neoblasts that are uniformly distributed throughout the body.

Once the individual progenitor populations have been specified, each is characterized by the expression of specific transcription factors required for their final differentiation into distinct cell fates. For example, ap-2 is required for the differentiation of $\operatorname{TrpA}^{+}$neurons (Wenemoser et al., 2012), klf for mechanoreceptor sensory neurons (Scimone et al., 2014b), pax3/7 for $\mathrm{DBH}^{+}$(dopamine- $\beta$ hydroxylase) neurons (Scimone et al., 2014b), Ihx1/5-1 and pitxfor serotonergic neurons (Currie et al., 2013; März et al., 2013), foxA for the pharynx (Adler et al., 2014), and foxD and prep for cells of the anterior pole (Scimone et al., 2014a). However, researchers have only recently begun to identify the genes and signaling pathways that are activated downstream of these transcription factors during the final stages of differentiation of these progenitors. Below, we review current knowledge of the differentiation of several cell types.

\section{Gut cells}

The planarian digestive system consists of highly ramified branches that expand to occupy almost the entire body (except in the anterior-most region), thereby ensuring that nutrients are distributed to all cells and thus compensating for the absence of a circulatory system. At the cellular level, the digestive system is a monostratified epithelium composed of two cell types, phagocytes and secretory goblet cells, surrounded by enteric musculature. Regeneration of the gut is accomplished by the differentiation of stem cells and remodeling of the pre-existing gastrodermis (Forsthoefel et al., 2011). In a remarkable RNAi screening study Forsthoefel and colleagues (2012) identified a set of genes expressed in phagocytes and required for several processes, including branching morphogenesis, phagocyte differentiation, and neoblast proliferation. One of those genes, a homologue of ceramide synthase, is required for the differentiation of functional phagocytes (Forsthoefel et al., 2012). Gut progenitors have been defined by the expression of two conserved transcription factors, hnf-4 and gata4/5/6, in Smedwi-1 positive cells (van Wolfswinkel et al., 2014; Scimone et al., 2014b; Wagner et al., 2011). In other animals, hnf-4 and gata4/5/6 are important for endodermal development (Ang et al., 1993; Murakami et al., 2005). Although no functional evidence supporting a role of $h n f-4$ in planarian regeneration has been published to date, the silencing of gata $4 / 5 / 6$ gives rise to severe defects in gut regeneration and maintenance that ultimately result in death, suggesting an important role of this gene in gut cell differentiation and survival (Flores et al., 2016; González-Sastre et al., 2017). A recent study demonstrated a key role of the epidermal growth factor receptor (EGFR) signaling pathway in the differentiation of gut progenitors during regeneration and homeostasis (Barberán et al., 2016a). Smed-egfr-1 is one of several planarian homologues of the EGFR family of tyrosine kinase receptors (Barberán et al., 2016b) and is 
expressed in differentiated gut cells and in gut progenitors in the mesenchyme around the gut branches (Barberán et al., 2016a). Whereas Smed-egfr-1 silencing inhibits the differentiation of new gut cells, as demonstrated in EdU incorporation experiments, the number of gut progenitors defined by co-expression of hnf4/SMEDWI-1 and gata4/5/6/SMEDWI-1 increases significantly. These results strongly suggest that Smed-egfr-1 is not required for the specification of gut progenitors but is required for their differentiation into mature phagocytes and goblet cells (Barberán et al., 2016a). In this same study, the authors identified a putative ligand of Smed-egfr-1 named Smed-nrg-1, which shares homology with neuregulin-type EGF ligands (Barberán et al., 2016b). The silencing of Smed-nrg-1 phenocopies the defects observed after knockdown of Smed-egfr-1, supporting the hypothesis that Smed-nrg-1 may act as a ligand of Smed-egfr-1 in vivo, thereby regulating the differentiation of gut progenitors. Further experiments will need to determine whether Smed-egfr-1 expression is regulated by $h n f-4$ and/or gata $4 / 5 / 6$, and characterize the cell type(s) in which Smed-nrg-1 is expressed.

\section{Epidermis}

The planarian epidermis is a monostratified layer consisting of a number of non-ciliated and ciliated cell types. Intercalated between the epidermal cells are specialized mucus-secreting rhabditic cells, as well as the ducts of mesenchymal secretory cells that open to the outside. The secreted mucus is thought to play a protective role and to facilitate gliding locomotion. The epidermal cells are strongly polarized, with cilia and microvilli at the apical end, lateral septate junctions, and hemidesmosomes at the basal end. Of all planarian cell types the epidermal lineage is among the best characterized. A subclass of neoblasts, named zeta-neoblasts, appear to be involved in epidermal regeneration and homeostatic cell turnover (van Wolfswinkel et al., 2014). Transcription factor $z f p-1$ is specific to zeta neoblasts and its silencing results in a significant decrease in the number of newly differentiated epidermal cells (van Wolfswinkel et al., 2014). More recently, several intermediate cellular stages between undifferentiated zeta-neoblasts and mature epidermal cell types have been identified (Tu et al., 2015). In 2008 Eisenhoffer and collaborators identified the genes NB21.11e (currently renamed prog-1) and AGAT-1 as markers of early and late neoblast progeny, respectively (Eisenhoffer et al., 2008). That conclusion was based on the time required for the depletion of those populations after the elimination of all neoblasts by lethal irradiation. NB21.11e-expressing cells disappear earlier than AGAT-1-expressing cells. Moreover, these early and late neoblast progeny are spatially separated, with the early progeny located deeper in the mesenchyme and the late progeny located closer to the outside. prog-1-and AGAT-1-positive cells are derived from zeta-neoblasts, placing them in the epidermal lineage (van Wolfswinkel et al., 2014). A current model of epidermal lineage differentiation proposes that zeta neoblasts gives rise to prog-1 cells through the activity of $z f p-1$, and that prog- 1 cells in turn give rise to AGAT-1 cells from which zpuf-6-expressing descendants emerge. Finally, zpuf- 6 cells differentiate into different mature epidermal cell types including multi-ciliated cells and marginal adhesive cells (Tu et al., 2015). In agreement with previous reports describing spatial separation of prog-1 and AGAT-1, zpuf- 6 cells are mainly found within or just below the epidermis, whereas AGAT-1 cells are located deeper within the mesenchyme. The different stages of the epidermal lineage are thus spatially segregated, with the zeta neoblasts located deepest in the mesenchyme and zpuf- 6 cells closer to the outside. More recently, other transcription factors such as soxP-3, pax-5 and p53 have been shown to participate in the differentiation of the epidermal lineage (Cheng et al., 2018).

A key element in the differentiation of the epidermal lineage is egr-5, a member of the "early growth response" family of zincfinger transcription factors. Planarian egr- 5 is mainly co-expressed with $A G A T-1$ in epidermal progenitors, and is barely expressed in mature epidermal cells. egr-5 silencing leads to a significant decrease in the number of mature epidermal cells and the numbers of AGAT-1- and zpuf-6-expressing progenitors, ultimately resulting in the loss of epidermal integrity, suggesting a key role of egr-5 in the differentiation of epidermal progeny cells (Tu et al., 2015). Remarkably, although egr-5 silencing does not affect the differentiation of cell lineages other than the epidermal lineage, it results in the expansion of neoblast populations and increases numbers of multiple lineage progenitors, including zeta-neoblasts. How the loss of epidermal integrity is sensed by neoblasts and why neoblast expansion occurs after egr-5RNAi silencing remain to be elucidated. It has been proposed that this expansion may be part of a stress response to cope with the loss of epidermal integrity (Tu et al., 2015). Interestingly, a similar scenario has been described for the gut lineage: silencing of Smed-egfr-1 leads to the gradual loss of the digestive system, since gut progenitors are unable to fully differentiate. The increase in the neoblast population and in proliferation observed in these same animals may constitute one element of a general stress response (Barberán et al., 2016a), a view supported by the similar effects observed after egr-5silencing.

\section{Central nervous system}

One of the most astonishing regenerative abilities of freshwater planarians is their ability to regrow a complete functional central nervous system (CNS) de novo from a tiny portion of the organism (Ross etal., 2017). The planarian CNS consists of an anterior bilobed brain or cephalic ganglia connected by a transverse commissure, lying on top of two ventral nerve cords that extend throughout the length of the animal (Agata et al., 1998; Cebrià et al., 2002b). In contrast to its apparent morphological simplicity, the planarian CNS displays a high degree of molecular sub-compartmentalization and complexity (Umesono et al., 1999; Cebrià et al., 2002c), and a wide range of neuronal types (reviewed in Cebrià, 2007; Ross et al., 2017). These include cholinergic (Nishimura et al., 2010), GABAergic (Nishimura et al., 2008a), dopaminergic (Nishimura et al., 2007a), octopaminergic (Nishimura et al., 2008b), serotonergic (Nishimura et al., 2007b; Cebrià, 2008), and neuropeptide F- and GYRFamide-positive (Cebrià, 2008) neurons, as well as several other subpopulations characterized by the expression of specific neuropeptides (Collins et al., 2010).

Recent studies have begun to elucidate how neoblasts are specified into the different neuronal lineages. Molinaro and coworkers, using a combination of single-cell sequencing and in silico lineage tracing methodologies, identified a novel neoblast population that may act as neural stem cells (Molinaro and Pearson, 2016). According to the model proposed by those authors, this subpopulation of neoblasts, termed $v$ Neoblasts (nu-Neoblasts), is defined by the expression of Smedwi-2 mRNA, SMEDWI-1 protein, and a set of neural-specific transcription factors. These vNeoblasts are typically found in the stem cell compartment adjacent to the 
brain, and are derived from the apparently pluripotent population of sigma-neoblasts (van Wolfswinkel et al., 2014). They migrate to the cephalic ganglia, where they are integrated as mature differentiated neurons (Molinaro and Pearson, 2016). If we assume that $v$ Neoblasts give rise to the large diversity of planarian neuronal populations, the next challenge is to identify the factors responsible for their specification from $v$ Neoblasts. To this end, several populations of progenitor cells specific for different neuronal types have been characterized in recent years based on their expression of distinct transcription factors. For example, pitx and $I h \times 1 / 5-1$ are required for the differentiation of serotonergic neurons; soxB2-2 for dopaminergic neurons (Roberts-Galbraith et al., 2016); pax3/7 for DBH (dopa- $\beta$-hydroxylase) neurons (Scimone et al., 2014b); runt for the expression of markers such as ovo and sp6-9, which specify photoreceptor and pigment cell progenitors, and $k / f$ and ap2, which are required for the differentiation of mechanosensory and $\operatorname{TrpA}$ neurons, respectively (Roberts-Galbraith et al., 2016; Lapan and Reddien, 2011, 2012; Currie et al., 2013; März et al., 2013; Wenemoser et al., 2012; Scimone et al., 2014b). runt appears to be required for the specification of several distinct neuronal lineages. Transcription factors belonging to the bHLH family are also expressed in neural progenitors capable of giving rise to several mature neuronal types (Cowles et al., 2013, 2014). These include planarian homologues of sim, coe, and hesl-3, which are expressed in mature neurons and in progenitor cells that continue to express the neoblast marker Smedwi-1 and are located in the mesenchyme in close proximity to the CNS (Cowles et al., 2013, 2014). coe expression has been demonstrated in mature cholinergic, GABAergic, octopaminergic, dopaminergic, and serotonergic neurons, while sim is expressed in octopaminergic and dopaminergic neurons (Cowles et al., 2013). The silencing of these two genes results in the regeneration of smaller brains in which several neuronal types are markedly under-represented (Cowles et al., 2013). Given the large number of transcription factors that have been associated with planarian neural progenitors, and the large diversity of neuronal types found in these animals, further research will be required to better understand how these different cell types are specified and differentiate from putative vNeoblasts. Similarly, more studies are required to characterize the mechanisms by which these transcription factors regulate the terminal differentiation of planarian neurons (i.e., to identify downstream elements and/or determine how transcription factors interact with different signaling pathways). Two recent studies have described the role of the Hedgehog and Wnt/ $\beta$-catenin pathways in neural cell differentiation (Currie et al., 2016; Sureda-Gómez et al., 2016). Silencing of $\beta$-catenin- 1 results in the regeneration of smaller brains containing reduced numbers of octopaminergic and dopaminergic neurons (Sureda-Gómez et al., 2016). The transcription factors $n k x 2.1$ and arx are expressed in some ventralmedial (VM) neuronal types, including cholinergic, GABAergic, and octopaminergic neurons, and in Smedwi-1-expressing progenitors. The silencing of these transcription factors results in a decrease in the size of these populations, indicating a role in their maintenance (Currie et al., 2016). Moreover, many of these VM neurons also express hedgehog $(h h)$, and the number of $h h$-positive cells decreases after arx RNAi. Remarkably, some stem cells located in the mesenchyme between the two cephalic lobes express the patched $(p t c)$ receptor, suggesting that they may respond to the $\mathrm{Hh}$ signal originating in VM neurons. Interestingly, $h h$ silencing results in significant reductions in several populations of neural progenitors, including those defined by the expression of $/ h \times 1 / 5-1$, coe, nk2-1, and arx. Based on these observations, a model has been proposed in which hh expression by VM neurons in the brain signals to stem cells in the mesenchyme, thereby regulating their differentiation into neurons to maintain homeostatic neurogenesis (Currie et al., 2016).

Many transcription factors and signaling pathway have been implicated in the specification and differentiation of the wide range of neuronal types found in planarians. Future studies incorporating the use of lineage-tracing tools should help improve our understanding of the mechanisms involved in their differentiation.

\section{Eye cells}

Planarians have simple eyes consisting of 2 cell types: pigment cells and photoreceptors. Pigment cells form a pigmented optic cup surrounding the cell bodies of clustered photoreceptors, which are bipolar neurons with rhabdomeric dendrites facing the pigment cup and visual axons that project to a specific region of the cephalic ganglia (Okamoto et al., 2005). While some visual axons project ipsilaterally to the brain, others do so contralaterally, giving rise to the optic chiasm. The overall projection pattern of visual axons is quite stereotypical, and several studies have uncovered the key functions of genes involved in the guidance of these axons (Cebrià and Newmark, 2005; Cebrià et al., 2007; Almuedo-Castillo etal., 2011). Specific transcription factors regulate the differentiation of pigment cells and photoreceptors. In the case of pigment cells, sp6-9 and $d l x$ are expressed in mature cells and in their specialized progenitors. Silencing of those genes results in animals that are unable to regenerate eye pigment cells, but does not affect photoreceptor cell differentiation (Lapan and Reddien, 2011). Remarkably, during regeneration, eye pigment progenitors expressing sp6-9 and $d l x$ form a trail of cells behind to the newly differentiating eyes. In fact, a gradient of differentiation is observed, such that the cells farthest from the new eyecups are committed undifferentiated progenitors co-expressing sp6-9 and the proliferation marker histone $h 2 b$, while those closer to the eyecups continue to express sp6-9, together with markers of mature differentiated cells (e.g., tyrosinase) (Lapan and Reddien, 2011). Silencing of either $d / x$ or sp6-9 prevents the regeneration of pigment cell progenitors, indicating a key role of these transcription factors in the specialization of neoblasts towards the pigment cell lineage (Lapan and Reddien, 2011). In fact, specification of the eye lineage implies several additional transcription factors, many of which interact with one another to specify progenitors of both photoreceptors and pigment cells. The earliest stage of neoblast specification towards the eye lineage appears to be determined by co-expression of the transcription factors ovo, sine oculis, and eya (Pineda et al., 2000; Mannini et al., 2004; Lapan and Reddien, 2012). The descendants of those progenitors then split into the lineages that give rise to each mature eye cell type (Lapan and Reddien, 2011, 2012). Photoreceptor cells do not constitute a homogeneous cell population, as they can be divided into anterior, posterior dorsal, and posterior ventral subpopulations based on the expression of different neuropeptide-encoding genes. Anterior cells are positive for eye53-1 and npp-12, posterior dorsal cells co-express eye53-2 and $\mathrm{mpl}-2$, and posterior ventral photoreceptors express $\mathrm{mpl}-2$ (Collins et al., 2010). While it remains unclear how posterior photoreceptors are specified from intermediate 
progenitors expressing $\operatorname{ot} x A$, anterior photoreceptors appear to be characterized by the expression of the transcription factor sox $B$ (Lapan and Reddien, 2012).

In addition, other genes and pathways have also been implicated in eye cell differentiation. Silencing of Smed-smad6/7-1, a homologue of the inhibitory SMAD proteins that regulate the BMP pathway, inhibits differentiation of the anterior photoreceptor cells without affecting posterior photoreceptor cells (González-Sastre et al., 2012). Following Smed-smad6/7-1 knockdown, the number of eye pigment cells during the initial stages of regeneration is similar to that of controls (González-Sastre et al., 2012). However, this number decreases as regeneration, suggesting that Smed-smad6/7-1 is also directly involved in the differentiation of eye pigment cells, or that this decrease is indirectly caused by the decrease in photoreceptor cell number. Indeed, a relationship between the differentiation of both eye cell types has been proposed. For example, when eye pigment cells fail to differentiate after silencing of $d l x$ or sp6-9, the visual axons of photoreceptors are often mistargeted (Lapan and Reddien, 2011). Moreover, silencing of Smed-egfr-1 results in a decrease in the number of regenerated eye pigment cells, in addition to the aforementioned defects observed in the gut (Fraguas et al., 2011). Although the number of photoreceptor cells is unaffected by Smed-egfr-1 silencing, the clustering of their cell bodies is abnormal (Fraguas et al., 2011). Studies of the BMP pathways have found that low-dose inhibition of Smed-bmp results in the regeneration of abnormally patterned eyes with an increased number of anterior photoreceptor cells (González-Sastre et al., 2012). These results suggest that BMP signaling is involved in the differentiation of the anterior photoreceptor population (González-Sastre et al., 2012). Future experiments will need to determine whether bmp, smad6/71 , and egfr-1 are expressed exclusively in mature eye cells or also in eye progenitor cells, and to identify any transcription factors that regulate their expression.

Finally, a recent study has shown that a novel $\beta$-catenin homologue named Smed- $\beta$-cat4 appears to act as a dominant-negative regulator of Smed- $\beta$-cat1 to control eye regeneration (Su et al., 2017). Thus, planarians in which $S m e d-\beta$-cat 4 is silenced regenerate smaller eyes containing fewer photoreceptors and pigment cells. Remarkably, Smed- $\beta$-cat4 is expressed in ovo-positive progenitor cells but is not co-expressed with sp6-9 (Su et al., 2017). This suggests that either (i) Smed- $\beta$-cat4 is involved in the specification of the earliest neoblast descendants that give rise to the eye cell lineage, and from which both photoreceptor and intermediate pigment cell progenitors originate; or ii) Smed- $\beta$-cat4 specifies the photoreceptor lineage, and the defects observed in pigment cell differentiation are an indirect consequence of the decrease in photoreceptor cell number caused by Smed- $\beta$-cat 4 silencing, similar to the situation observed after of Smed-smad6/7 silencing.

\section{Excretory system}

The planarian excretory system consists of epithelial tubules known as protonephridia, which are distributed throughout the entire body. This system includes a series of tubules formed by terminal flame cells, the cilia of which drive filtration. The recent identification of a variety of molecular markers has enabled better characterization and visualization of these complex structures (Rink et al., 2011; Scimone et al., 2011). The Smed-DNAH- $\beta 3$ (dynein heavy chain) homologue is expressed in terminal flame cells; Smed-innexin-10 and Smed-rootletin are expressed in intermediate ciliated tubules connected to flame cells; and Smed-CAVII-1 (a carbonic anhydrase homologue) is expressed in non-ciliated distal tubules (Rink et al., 2011; Scimone et al., 2011). Protonephridia progenitors express some conserved transcription factors, such as Six1/2-2, pou2/3, and Sall, the silencing of which impairs protonephridia regeneration and maintenance (Scimone et al., 2011). In fact, the silencing of Six 1/2-2 or pou2/3 inhibits the generation of progenitor cells, which may explain the subsequent failure to regenerate and maintain the excretory system (Scimone et al., 2011). A current model thus proposes that progenitor cells co-express Six 1/2-2 and pou2/3 and that descendants from this population terminally differentiate into at least 2 populations: intermediate ciliated tubules, which express Six1/2-2 and rootletin; and distal non-ciliated tubules, which express pou2/3 and CAVII-1 (Scimone et al., 2011). It remains to be determined whether terminal flame cells are also derived from these progenitors.

The EGFR signaling pathway has been also implicated in the regeneration and maintenance of the excretory system (Rink et al., 2011; Barberán et al., 2016b). Smed-egfr-5 is expressed in flame cells and in adjacent ciliated tubules and its silencing results in edema formation, aberrant cell morphology and overall branching pattern as well as in the reduction of flame cells (Rink et al., 2011). The silencing of Smed-egf- 6 induces edema and defects in the expression of Smed-CAVII-1, suggesting that it may function as a ligand of Smed-egfr-5 to regulate regeneration and maintenance of the excretory system (Barberán et al., 2016b).

In summary, planarian pluripotent stem cells give rise to different populations of descendant progenitors that become specified to differentiate into discrete lineages based on the expression of distinct sets of transcription factors. Once specified, additional transcription factors and/or different signaling pathways can regulate their final differentiation (Fig. 5). Moreover, it appears that specialized progenitors are usually found around the region in which the tissues derived from them will be required during regeneration, suggesting that local signals may control the specification of pluripotent neoblasts towards their final fates. Similarly, during homeostatic cell turnover, progenitors are found in close proximity to the tissues that they will renew, further supporting the view that local signals regulate neoblast differentiation. In addition to the cell-cell communication signals (Wnt, BMP, FGF, and EGF) already mentioned in the preceding sections, recent studies have highlighted the importance of cell-extracellular matrix signaling interactions in the correct positioning of progenitor cells and the regeneration of patterned tissues (Bonar and Petersen, 2017; Seebeck et al., 2017).

\section{Size control and organ proportionality}

The majority of animal species have a defined body shape and size in adulthood, and their organs attain a specific size proportional to total body size. The ability of planarians to regenerate from any fragment is dependent upon a robust mechanism that allows the adjustment of organ size as appropriate. During regeneration planarians adjust their final size to the size of the original fragment, thus resulting in well-proportioned body parts, in which new and pre-existing tissues are integrated. While the blastema regenerates some of the missing organs, in some fragments organs such as the pharynx or the reproductive system are regenerated in the pre-existing tissue. Thus, during regeneration extensive and tightly 
controlled remodeling of the existing tissue takes place, mediated by cellular death via apoptosis and autophagy (Pelleteri et al., 2010; González- Estévez et al., 2007). The molecular signals that control blastema size in planarians are those involved in regulating cell death and proliferation, and include the JNK signaling pathway, the mTOR pathway and the Hippo pathway. As described above, in planarians JNK translates the wound signals into apoptotic cell death and controlled stem cell proliferation (Almuedo-Castillo et

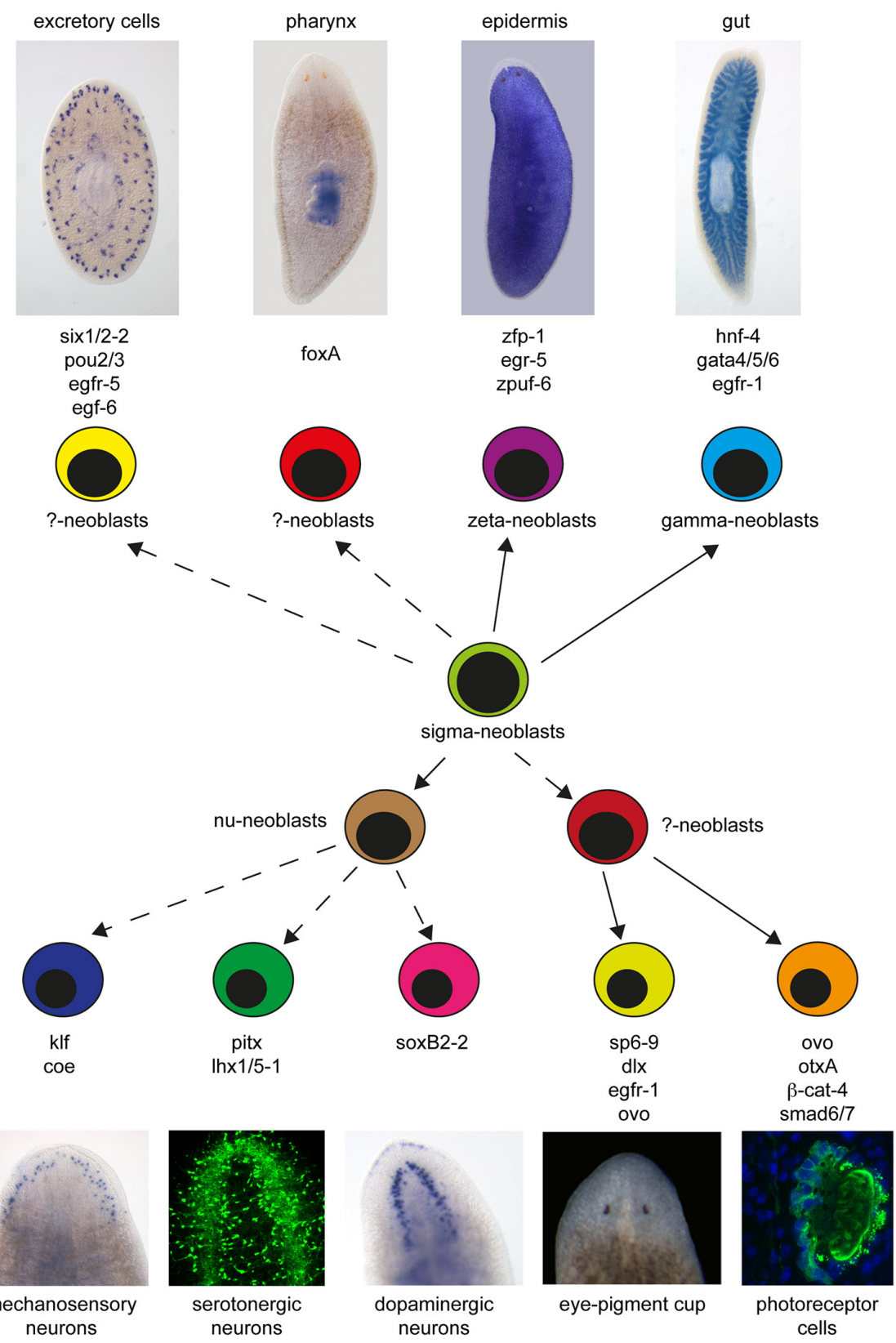

Fig. 5. Model of planarian cell differentiation from pluripotent stem cells. Pluripotent sigma-neoblasts give rise to distinct specialized descendants expressing specific transcription factors, which commit them to different mature cells types. Thus, zeta-neoblasts give rise to the epidermal lineage, gamma-neoblasts give rise to the gut cell lineage, and nu-neoblasts give rise to different neuronal lineages specified by distinct sets of transcription factors. Progenitors of other tissues such as the pharynx, excretory cells, and eyes are also likely derived from pluripotent sigma-neoblasts. Some images courtesy by Susanna Fraguas. al., 2014). Consequently, JNK RNAi results in the regeneration of tiny blastemas, and prevents the remodeling of existing tissue. Interestingly, the inhibition of genes that impede proper blastema regeneration prevents remodeling and re-patterning of existing tissue to match the new body size. For instance, inhibition of $p b x$, which is required to establish organizing centers in blastemas, not only inhibits differentiation of the missing tissues but also impairs re-scaling of the "posterior Wnts" expression gradient (Blassberg et al., 2013; Chen et al., 2013).

Inhibition of the Insulin receptor in planarians prevents their growth after feeding (Miller and Newmark2012). The TOR signal is an evolutionary conserved pathway that integrates nutrient status with cell growth and division (Loewith et al., 2011). Although its role in relation to the nutritional status of planarians has not been uncovered, its inhibition in regenerating planarians leads to the inability to form blastemas and to remodel the pre-existing tissues (Peiris et al., 2012, Tu et al., 2012). The inhibition of PTENand smg-1 in planarians produces overproliferation and outgrowths that are rescued by Rapamycin, a TOR pathway inhibitor (Oviedo et al., 2008; González-Estévez et al., 2012). Those results show the relevance of the insulin-TOR pathway in the control of growth in planarians, although further studies are required for a deeper understanding. The Hippo pathway is a conserved signaling pathway that integrates signals controlling proliferation, cell death, and differentiation during development (Pfleger, 2017). While inhibition of yki results in blotted planarians due to altered homeostasis of the excretory system (Lin and Pearson 2014), in-depth molecular analyses have shown that $y k i$ RNAi animals display a hyper-activated wound response (Lin and Pearson 2017). Thus, inhibition of $y k i$ induces blastema regeneration, with increases both in cell number and in the number of differentiated cells. This finding appears to contradict the reported role of $y k i$ in other regenerative contexts; in both zebrafish and mice hippoinhibition (which induces Yki phosphorylation and nuclearization) activates the regenerative response (Zhou et al., 2015; Loforese et al., 2016). However, we recently found that hippo inhibition (i.e., Yki activation) in planarians promotes cell plasticity and acquisition of stemness (de Sousa et al., 2018). While this effect does not promote a regenerative response, it is in agreement with the reported role of $\mathrm{Yki}$ as a stemness promoter in other models (Pfleger, 2017). It is possible that hippo inhibition (i.e., yki activation) in planarians fails to facilitate regeneration because cell dedifferentiation fuels the regenerative response in vertebrate regenerative systems (Yanger et al., 2013; Kikuchi, 2015), whereas expansion of the stem cell population is the only source of new cells in planarians. 
In planarians the Hippo signaling cascade controls the wound response and plays a crucial role during cell differentiation. However, it does not directly regulate organ size, as described in other systems (Pfleger, 2017). In one of the few studies to shed light on the molecular mechanisms that regulate organ size in planarians, Petersen and coworkers examined the maintenance of the brain proportion with respect to body size (Hill and Petersen 2015). They found that notum, which is expressed in the anterior part of the brain, and wnt11-6, expressed in the posterior region of the brain, form an inhibitory spatial feedback loop that regulates planarian brain size through reversible regenerative growth. Using RNAi inhibition of notum and Wnt11-6, and analysis of cintillo (a marker of head chemoreceptors, numbers of which are constantly correlated with body size (Oviedo et al., 2003), they found that wnt11-6 inhibits the division of brain progenitors. Based on their findings, they proposed that wnt11-6, via the canonical Wnt pathway, activates the expression of its own inhibitor, notum, in the anterior brain, which in turn promotes brain growth by inhibiting wnt11-6. Importantly, Wnt signaling appears to be required to control brain size, but not brain patterning.

\section{Conclusions}

Regeneration is a fascinating biological process that occurs naturally in a large variety of animals. Among all of them, freshwater planarians are one of the champions, as they can regrow, for example, a complex CNS de novo from almost any piece of their bodies. The active research in the planarian field in the last years has provided essential data to understand the main events that leads to a successful regeneration. According to the genetic and cellular response, three different phases can be distinguished. Following, we highlight the main discoveries as well as the main gaps still present in each one:

The early response is characterized by the triggering of a generic regenerative program, likely induced by ERK signaling, in which genes related with cell death (apoptosis and autophagy), and stress (JNK and ROS) are activated. In contrast to other models, it is currently unknown whether the apoptotic cells are the source of proliferative or survival signals, neither the relationship between apoptosis and the activation of ROS.

The injury-specific response is characterized by the activation of the specific program to regenerate the missing tissues. The molecular nature of the $\mathrm{A}$ and the $\mathrm{P}$ organizing centers has been broadly described. And the discovery of the PCGs has been one of the main recent advances in the field. However, the precise mechanism that triggers the regeneration of the appropriate $A$ versus $\mathrm{P}$ organizer in each wound after any type of amputation remains a mystery.

The late phase corresponds to the differentiation and morphogenesis of the new organs. A great advance has been seen in the discovery of the specific transcription factors that give rise to specific lineages arising from neoblasts, which are nowadays clearly seen as a heterogeneous population of stem cells, including true pluripotent stem cells and subpopulations of lineage-committed progenitors. However, many cell types as well as the origin of several lineages are still waiting to be molecularly uncovered.

In contrast to other models, especially vertebrates, planarian regeneration relies on the proliferative potential of their adult pluripotent stem cells, the neoblasts, and not in a process of dedifferentiation. The potency of planarian adult stem cells, the evolutionary conservation of the main molecular signals, and the malleability of the model, makes planarians very attractive not only to understand the basic mechanisms of regeneration, but also for the implications it may have in the field of regenerative medicine.

\section{Acknowledgements}

We would like to thank all members past and present of our laboratories for their contributions to the planarian field and José Ignacio Rojo for figures 2 and 3. We thank Owen Howard for English editing. This work was supported by grants BFU2014-56055P and BFU2017-83755-P from Ministerio de Economía y Competitividad (Spain) to E.S. and T.A., and BFU2015-65704P from Ministerio de Economía y Competitividad (Spain) to F.C, and grant 2014SGR-2016 from AQU (Generalitat de Catalunya).

\section{References}

ABNAVE, P., ABOUKhatWA, E., KOSAKA, N., THOMSON, J., HILL, M.A., ABOOBAKER, A. (2017). Epithelial-msenchymal transition transcription factors control pluripotent adult stem cell migration in vivo in planarians. Development 144: 3440-3453.

ADELL, T., SALÒ, E., BOUTROS, M., BARTSCHERER, K. (2009). Smed-Evi/Wntless is required for beta-catenin-dependent and -independent processes during planarian regeneration. Development 136: 905-910.

ADELL, T., CEBRIÀ, F., SALÓ, E. (2010).Gradients in planarian regeneration and homeostasis. Cold Spring Harb Perspect Biol. doi:10.1101/cshperspect.a000505.

ADLER, C.E., SEIDEL, C.W., McKINNEY, S.A., SÁNCHEZ-ALVARADO, A. (2014). Selective amputation of the pharynx identifies a FoxA-dependent regeneration program in planaria. eLife 3: e02238.

AGATA, K., SOEJIMA, Y., KATO, K., KOBAYASHI, C., UMESONO, Y., WATANABE, K. (1998). Structure of the planarian central nervous system (CNS) revealed by neuronal cell markers. Zoolog Sci 15: 433-440.

ALFADDA, A.A., SALLAM, R.M. (2012). Reactive oxygen species in health and disease. J Biomed Biotec 2012: 936486.

ALMUEDO-CASTILLO, M., SALÓ, E., ADELL, T. (2011). Dishevelled is essential for neural connectivity and planar cell polarity in planarians. Proc Natl Acad Sci USA 108: 2813-2818.

ALMUEDO-CASTILLO, M., SUREDA-GÓMEZ, M., ADELL, T. (2012). Wnt signaling in planarians: new answers to old questions. Int J Dev Biol 56: 53-65.

ALMUEDO-CASTILLO, M., CRESPO-YANEZ, X., SEEBECK, F., BARTSCHERER, K., SALÒ, E., ADELL., T. (2014). JNK controls the onset of mitosis in planarian stem cells and triggers apoptotic cell death required for regeneration and remodeling. PLoS Genet 10: e1004400.

ANG, S.L., WIERDA, A., WONG, D., STEVENS, K.A., CASCIO, S., ROSSANT, J., ZARET, K.S. (1993). The formation and maintenance of the definitive endoderm lineage in the mouse: involvement of HNF3/forkhead proteins. Development 119: 1301-1315.

BARBERÁN, S., FRAGUAS, S., CEBRIÀ, F. (2016a). The EGFR signaling pathway controls gut progenitor differentiation during planarian regeneration and homeostasis.Development 143: 2089-2102.

BARBERÁN, S., MARTÍN-DURÁN, J.M., CEBRIÀ, F. (2016b). Evolution of the EGFR pathway in Metazoa and its diversification in the planarian Schmidtea mediterranea. Sci Rep 6: 28071.

BERGANTIÑOS, C., COROMINAS M, SERRAS,F. (2010). Cell death-induced regeneration in wing imaginal discs requires JNK signalling. Development 137: 1169-1179.

BLASSBERG, R.A., FELIX, D.A., TEJADA-ROMERO, B., ABOOBAKER, A.A. (2013). $\mathrm{PBX} / \mathrm{extradenticle} \mathrm{is} \mathrm{required} \mathrm{to} \mathrm{re-establish} \mathrm{axial} \mathrm{structures} \mathrm{and} \mathrm{polarity} \mathrm{during}$ planarian regeneration. Development 140: 730-739.

BEANE, W.S., MOROKUMA, J., ADAMS, D.S., LEVIN, M. (2011). A chemical genetics approach reveals $\mathrm{H}, \mathrm{K}$-ATPase-mediated membrane voltage is required for planarian head regeneration. Chem Biol 18: 77-89.

BONAR, N.A., PETERSEN, C.P. (2017). Integrin suppresses neurogenesis and regulates brain tissue assembly in planarian regeneration. Development 144: 784-794.

CEBRIÀ, F. (2007). Regenerating the central nervous system: how easy for planar- 
ians! Dev Genes Evol 217: 733-748.

CEBRIÀ, F. (2008). Organization of the nervous system in the model planarian Schmidtea mediterranea: an immunocytochemical study. NeurosciRes61:375-384.

CEBRIÀ, F., KOBAYASHI, C., UMESONO, Y., NAKAZAWA, M., MINETA, K., IKEO, K., GOJOBORI, T., AGATA, K. (2002a). FGFR-related gene nou-darake restricts brain tissues to the head region of planarians. Nature 419: 620-624.

CEBRIÀ, F., NAKAZAWA, M., MINETA, K., IKEO, K., GOJOBORI, T., AGATA, K. (2002b). Dissecting planarian central nervous system regeneration by the expression of neural-specific genes. Dev Growth Differ 44: 135-146.

CEBRIÀ, F., KUDOME, T., NAKAZAWA, M., MINETA, K., IKEO, K., GOJOBORI, T., AGATA, K. (2002c). The expression of neural-specific genes reveals the structural and molecular complexity of the planarian central nervous system. Mech Dev 116: 199-204.

CEBRIÀ, F., NEWMARK, P.A. (2005). Planarian homologs of netrin and netrin receptor are required for proper regeneration of the central nervous system and the maintenance of nervous system architecture. Development 132: 3691-3703.

CEBRIÀ, F., NEWMARK, P.A. (2007). Morphogenesis defects are associated with abnormal nervous system regeneration following roboA RNAi in planarians. Development 134: 833-837.

CHANDEBOIS R. (1980). The dynamics of wound closure and its role in the programming of planarian regeneration. II-Distalization. Dev. Growth Differ. 22: 693-704

CHEN, C.C., WANG I.E., REDDIEN, P.W. (2013). pbx is required for pole and eye regeneration in planarians. Development 140: 719-729.

CHENG, L.C., TU, K.C., SEIDEL, C.W., ROBB, S.M.C., GUO, F., SÁNCHEZ ALVARADO, A. (2018). Cellula, ultrastructural and molecular analyses of epidermal cell development in the planarian Schmidtea mediterranea. Dev Bio/433:357-373.

COLLINS, J.J. 3rd, HOU, X., ROMANOVA, E.V., LAMBRUS, B.G., MILLER, C.M., SABERI, A., SWEEDLER, J.V., NEWMARK, P.A. (2010). Genome-wide analyses reveal a role for peptide hormones in planarian germline development. PLOS Biol 8: e1000509.

COWLES, M.W., BROWN, D.D., NISPEROS, S.V., STANLEY, B.N., PEARSON, B.J., ZAYAS, R.M. (2013). Genome-wide analysis of the bHLH gene family in planarians identifies factors required for adult neurogenesis and neuronal regeneration. Development 140: 4691-4702.

COWLES, M.W., OMURO, K.C., STANLEY, B.N., QUINTANILLA, C.G., ZAYAS, R.M. (2014). COE loss-of-function analysis reveals a genetic program underlying maintenance and regeneration of the nervous system in planarians. PLOS Genet 10: e1004746.

CURRIE, K.W., PEARSON, B.J. (2013). Transcription factors Ihx1/5-1 and pitx are required for the maintenance and regeneration of serotonergic neurons in planarians. Development 140: 3577-3588.

CURRIE, K.W., MOLINARO, A.M., PEARSON, B.J. (2016). Neuronal sources of hedgehog modulate neurogenesis in the adult planarian brain. eLife 5: e19735.

de SOUSA, N., RODRíGUEZ-ESTEBAN, G., ROJO-LAGUNA, J.I., SALÓ, E., ADELL, T. (2018). Hippo signaling restricts cell plasticity in planarians. PLoS Biol, 16 (1): e2002399.

DUBOIS, F. (1949). Contribution á l'étude de la migration des cellules de regeneration chez les planaires dulcicoles. Bull Biol Fr Belg 83: 213-283.

EISENHOFFER, G.T., KANG, H., SÁNCHEZ-ALVARADO, A. (2008). Molecular analysis of stem cells and their descendants during cell turnover and regeneration in the planarian Schmidtea mediterranea. Cell Stem Cell 3: 327-39.

FLORES, N.M., OVIEDO, N.J., SAGE, J. (2016). Essential role for the planarian intestinal GATA transcription factor in stem cells and regeneration. Dev Biol 418: $179-188$

FORSTHOEFEL, D.J., PARK, A.E., NEWMARK, P.A. (2011). Stem cell-based growth, regeneration, and remodeling of the planarian intestine. Dev Biol 356: 445-59.

FORSTHOEFEL, D.J., JAMES, N.P., ESCOBAR, D.J., STARY, J.M., VIEIRA, A.P., WATERS, F.A., NEWMARK, P.A. (2012). An RNAi screen reveals intestinal regulators of branching morphogenesis, differentiation, and stem cell proliferation in planarians. Dev Cell 23: 691-704.

FRAGUAS, S., BARBERÁN, S., CEBRIÀ, F. (2011). EGFR signaling regulates cell proliferation, differentiation and morphogenesis during planarian regeneration and homeostasis. Dev Biol 354: 87-101.

FRAGUAS, S., UMESONO, Y., AGATA, K., CEBRIÀ, F. (2017). Analyzing pERK activation during planarian regeneration. Methods Mol Biol 1487: 303-315.
GAURON, C., RAMPON, C., BOUZAFFOUR, M., IPENDEY, E., TEILLON, J., VOLOVITCH, M., VRIZ, S. (2013). Sustained production of ROS triggers compensatory proliferation and is required for regeneration to proceed. Sci Rep 3: 2084.

GAVINO, M.A., WENEMOSER, D., WANG, I.E., REDDIEN, P.,W. (2013).Tissue absence initiates regeneration through follistatin-mediated inhibition of activin signaling. eLife 2: e00247.

GONZÁLEZ-ESTÉVEZ, C., FELIX, D. A., ABOOBAKER, A. A., SALÓ, E. (2007) Gtdap-1 promotes autophagy and is required for planarian remodeling during regeneration and starvation. Proc Natl Acad Sci USA 104: 13373-13378.

GONZÁLEZ-ESTÉVEZ, C., FELIX, D.A., SMITH, M.D., PAPS, J., MORLEY, S.J., JAMES, V., SHARP, T.V., ABOOBAKER, A.A. (2012). SMG-1 and mTORC1 act antagonistically to regulate response to injury and growth in planarians. PLOS Genet 8: e1002619.

GONZÁLEZ-SASTRE, A., MOLINA, M.D., SALÓ, E. (2012). Inhibitory Smads and bone morphogenetic protein (BMP) modulate anterior photoreceptor cell number during planarian eye regeneration. Int J Dev Biol 56: 155-163.

GONZÁLEZ-SASTRE, A., DE SOUSA, N., ADELL, T., SALÓ, E. (2017). The pioneer factor Smed-gata456-1 is required for gut cell differentiation and maintenance in planarians. Int J Dev Biol 61: 53-63.

GUEDELHOEFER, O.C., SÁNCHEZ-ALVARADO, A. (2012). Amputation induces stem cell mobilization to sites of injury during planarian regeneration. Development 139: 3510-20.

GURLEY, K.A., RINK, J.C., SÁNCHEZ-ALVARADO, A. (2008). Beta-catenin defines head versus tail identity during planarian regeneration and homeostasis. Science 319: 323-327.

HAMEED, L.S., BERG, D.A., BELNOUE, L., JENSEN, L.D., CAO, Y., SIMON, A. (2015) Environmental changes in oxygen tension reveal ROS-dependent neurogenesis and regeneration in the adult newt brain. eLife 4: e08422.

HARFE, B.D. (2011). Keeping up with the zone of polarizing activity: New roles for an old signaling center. Dev Dyn 240: 915-919.

HAYASHI, T., MOTOISHI, M., YAZAWA, S., ITOMI, K., TANEGASHIMA, C., NISHIMURA, O., AGATA, K., TARUI, H. (2011). A LIM-homeobox gene is required for differentiation of Wnt-expressing cells at the posterior end of the planarian body. Development 138: 3679-3688.

HERNÁNDEZ-GARCÍA, D., WOOD, C.D., CASTRO-OBREGÓN, S., COVARRUBIAS, L. (2010). Reactive oxygen species: a radical role in development? Free Radic Biol Med 49: 130-143.

HILL EM, PETERSEN CP, (2015). Wnt/Notum spatial feedback inhibition controls neoblast differentiation to regulate reversible growth of the planarian brain. $D e-$ velopment 142: 4217-4229.

IGLESIAS, M., GÓMEZ-SKARMETA, J.L., SALÓ, E., ADELL, T. (2008). Silencing of Smed-betacatenin1 generates radial-like hypercephalized planarians. Development 135: 1215-1221.

ISOLANI, M.E., ABRIL, J.F., SALÓ,E., DERI, P., BIANUCCI,,A.M., BATISTONI, R.(2013). Planarians as a model to assess in vivo the role of matrix metalloproteinase genes during homeostasis and regeneration. PLoS One 8: e55649.

KIKUCHI, K. (2015). Dedifferentiation, transdifferentiation, and proliferation: mechanisms underlying cardiac muscle regeneration in zebrafish. Curr Pathobiol Rep 3: 81-88.

LANDER, R., PETERSEN, C.P. (2016). Wnt, Ptk7, and FGFRL expression gradients control trunk positional identity in planarian regeneration. eLife 5: e12850.

LAPAN, S.W., REDDIEN, P.W. (2011). dlx and sp6-9 control optic cup regeneration in a prototypic eye. PLoS Genet 7: e1002226.

LAPAN, S.W., REDDIEN, P.W. (2012). Transcriptome analysis of the planarian eye identifies ovo as a specific regulator of eye regeneration. Cell Rep 2: 294-307.

LEI, K., THI-KIM VU, H., MOHAN, R.D., McKINNEY, S.A., SEIDEL, C.W., ALEXANDER, R., GOTTING, K., WORKMAN, J.L., SÁNCHEZ-ALVARADO, A. (2016). Egf signaling directs neoblast repopulation by regulating asymmetric cell division in planarians. Dev Cell 38: 413-429.

LIN, A.Y., PEARSON, B.J. (2014). Planarian yorkie/YAP functions to integrate adult stem cell proliferation, organ homeostasis and maintenance of axial patterning. Development 141:1197-208.

LIN, A.Y., PEARSON, B.J. (2017). Yorkie is required to restrict the injury responses in planarians. PLOS Genet 13: e1006874.

LOBO, D., BEANE, W.S., LEVIN, M. (2012). Modeling planarian regeneration: a primer 
for reverse-engineering the worm. PLOS Comput Biol 8: e1002481.

LOEWITH, R., HALL, M.N. (2011). Target of rapamycin (TOR) in nutrient signaling and growth control. Genetics 189: 1177-1201.

LOFORESE, G., MALINKA, T., KEOGH, A., BAIER, F., SIMILLION, C., MONTANI, M., HALAZONETIS, T.D., CANDINAS, D., STROKA, D. (2016). Impaired liver regeneration in aged mice can be rescued by silencing Hippo core kinases MST1 and MST2. EMBO Mol Med 9: 46-60.

LOVE, NR., CHEN, Y., ISHIBASHI, S., KRITSILIGKOU, P., LEA, R., KOH, Y., GALLOP, J.L., DOREY, K., AMAYA, E. (2013). Amputation-induced reactive oxygen species are required for successful Xenopus tadpole tail regeneration. Nat Cell Biol 15: 222-228.

MANNINI, L., ROSSI, L., DERI, P., GREMIGNI, V., SALVETTI,A., SALÓ, E., BATISTONI, R. (2004). Djeyes absent (Djeya) controls prototypic planarian eye regeneration by cooperating with the transcription factor Djsix-1. Dev Biol 269: 346-359.

MÄRZ, M., SEEBECK, F., BARTSCHERER, K. (2013). A Pitx transcription factor controls the establishment and maintenance of the serotonergic lineage in planarians. Development 140: 4499-4509.

MOLINA, M.D., SALÓ, E., CEBRIÀ, F. (2011). Organizing the DV axis during planarian regeneration. Commun Integr Biol 4: 498-500.

MOLINARO, A.M., PEARSON, B.J. (2016). In silico lineage tracing through single cell transcriptomics identifies a neural stem cell population in planarians. Genome Biol 17: 87.

MILLER, C.M., NEWMARK, P.A. (2012). An insulin-like peptide regulates size and adult stem cells in planarians. Int J Dev Biol 56: 75-82.

MURAKAMI, R., OKUMURA, T., UCHIYAMA, H. (2005). GATA factors as key regulatory molecules in the development of Drosophila endoderm. Dev Growth Differ 47: 581-589.

NISHIMURA, K., KITAMURA, Y., INOUE, T., UMESONO, Y., SANO, S., YOSHIMOTO, K., INDEN, M., TAKATA, K., TANIGUCHI, T., SHIMOHAMA, S., AGATA, K. (2007a). Reconstruction of dopaminergic neural network and locomotion function in planarian regenerates. Dev Neurobiol 67: 1059-1078.

NISHIMURA, K., KITAMURA, Y., INOUE, T., UMESONO, Y., YOSHIMOTO, K., TAKEUCHI, K., TANIGUCHI, T., AGATA, K. (2007b). Identification and distribution of tryptophan hydroxylase (TPH)-positive neurons in the planarian Dugesia japonica. Neurosci Res 59: 101-106.

NISHIMURA, K., KITAMURA, Y., UMESONO, Y., TAKEUCHI, K., TAKATA, K., TANIGUCHI, T., AGATA, K. (2008a). Identification of glutamic acid decarboxylase gene and distribution of GABAergic nervous system in the planarian Dugesia japonica. Neuroscience 153: 1103-1114.

NISHIMURA, K., KITAMURA, Y., INOUE, T., UMESONO, Y., YOSHIMOTO, K., TANIGUCHI, T., AGATA, K. (2008b). Characterization of tyramine beta-hydroxylase in planarian Dugesia japonica: cloning and expression. Neurochem Int 53: 184-192.

NISHIMURA, K., KITAMURA, Y., TANIGUCHI, T., AGATA, K. (2010). Analysis of motor function modulated by cholinergic neurons in planarian Dugesia japonica. Neuroscience 168: 18-30.

ODERBERG, I.M., LI, D.J., SCIMONE, M.L., GAVIÑO, M.A., REDDIEN, P.W. (2017). Landmarks in existing tissue at wounds are utilized to generate pattern in regenerating tissue. CurR Biol 27: 733-742.

OKAMOTO, K., TAKEUCHI, K., AGATA, K. (2005). Neural projections in planarian brain revealed by fluorescent dye tracing. Zoolog Sci 22: 535-546.

OVIEDO, N.J., NEWMARK, P.A., SÁNCHEZALVARADO, A. (2003). Allometric scaling and proportion regulation in the freshwater planarian Schmidtea mediterranea. Dev Dyn 226: 326-333.

OVIEDO, N.J., PEARSON, B.J., LEVIN, M., SÁNCHEZ ALVARADO, A. (2008). Planarian PTEN homologs regulate stem cells and regeneration through TOR signaling. Dis Model Mech 1: 131-143.

OVIEDO, N.J., MOROKUMA, J., WALENTEK, P., KEMA, I.P., GU, M.B., AHN, J.M., HWANG, J.S., GOJOBORI, T., LEVIN, M. (2010). Long-range neural and gap junction protein-mediated cues control polarity during planarian regeneration. Dev Biol 339: 188-199.

OWLARN, S., BARTSCHERER, K. (2016). Go ahead, grow a head! A planarian's guide to anterior regeneration. Regeneration (Oxf).3: 139-155.

OWLARN, S., KLENNER, F., SCHMIDT, D., RABERT, F., TOMASSO, A., REUTER, H., MULAW, M.A., MORITZ, S., GENTILE, L., WEIDINGER, G., BARTSCHERER, K. (2018). Generic wound signals initiate regeneration in missing-tissue contexts.
Nature Comm 8: 2282

PEIRIS, T.H., WECKERLE, F., OZAMOTO, E., RAMÍREZ, D., DAVIDIAN, D., GARCÍAOJEDA, M.E., OVIEDO, N.J. (2012). TOR signaling regulates planarian stem cells and controls localized and organismal growth. J Cell Sci 125: 1657-1665.

PEIRIS,T.H., RAMIREZ,D., BARGHOUTH, P.G., OVIEDO, N.J. (2016). The Akt signaling pathway is required for tissue maintenance and regeneration in planarians. BMC Dev Biol 16: 7.

PELLETTIERI, J., FITZGERALD, P., WATANABE, S., MANCUSO, J., GREEN, D. R., SÁNCHEZ ALVARADO, A. (2010). Cell death and tissue remodeling in planarian regeneration. Dev Biol 338: 76-85.

PETERSEN, C.P., REDDIEN, P.W. (2008). Smed-betacatenin-1 is required for anteroposterior blastema polarity in planarian regeneration. Science 319: 327-330.

PETERSEN, C.P., REDDIEN, P.W. (2009). A wound-induced Wnt expression program controls planarian regeneration polarity. Proc NatlAcad SciUSA 106: 17061-17066.

PETERSEN, C.P., REDDIEN, P.W. (2011). Polarized notum activation at wounds inhibits Wnt function to promote planarian head regeneration. Science 332: 852-855.

PFLEGER, C.,M. (2017). The Hippo Pathway: AMaster Regulatory Network Important in Development and Dysregulated in Disease. Curr Top Dev Biol 123: 181-228.

PINEDA, D., GONZÁLEZ, J., CALLAERTS, P., IKEO, K., GEHRING, W.J., SALÓ, E. (2000). Searching for the prototypic eye genetic network: Sine oculis is essential for eye regeneration in planarians. Proc Natl Acad Sci USA 97: 4525-4529.

PIROTTE, N., STEVENS, A.S., FRAGUAS, S., PLUSQUIN, M., VAN ROTEN, A., VAN BELLEGHEM, F., PAESEN, R., AMELOOT, M., CEBRIÀ, F., ARTOIS, T., SMEETS, K. (2015). Reactive oxygen species in planarian regeneration: an upstream necessity for correct patterning and brain formation. Oxid Med Cell Longev 2015: 392476.

REDDIEN, PW, SÁNCHEZ-ALVARADO A. (2004). Fundamentals of planarian regeneration. Annu. Rev. Cell Dev. Biol. 20: 725-57

REDDIEN, P.,W. (2011). Constitutive gene expression and the specification of tissue identity in adult planarian biology. Trends Genet 27: 277-285.

REVERSADE, B., DE ROBERTIS, E.M. (2005). Regulation of ADMP and BMP2/4/7 at opposite embryonic poles generates a self-regulating morphogenetic field. Cell 123: 1147-1160.

RINK, J.C., GURLEY, K.A., ELLIOTT, S.A., SÁNCHEZ-ALVARADO, A. (2009). Planarian $\mathrm{Hh}$ signaling regulates regeneration polarity and links $\mathrm{Hh}$ pathway evolution to cilia. Science 326: 1406-1410.

RINK, J.C., VU, H.T., SÁNCHEZ-ALVARADO, A. (2011). The maintenance and regeneration of the planarian excretory system are regulated by EGFR signaling Development 138: 3769-3780.

ROBERTS-GALBRAITH, R.H., NEWMARK, P.A. (2013). Follistatin antagonizes activin signaling and acts with notum to direct planarian head regeneration. Proc Natl Acad Sci USA 110: 1363-1368.

ROBERTS-GALBRAITH, R.H., BRUBACHER, J.L., NEWMARK, P.A. (2016). A functional genomics screen in planarians reveals regulators of whole-brain regeneration. eLife 5: e17002.

ROSS, K.G., CURRIE, K.W., PEARSON, B.J., ZAYAS, R.M. (2017). Nervous system development and regeneration in freshwater planarians. Wiley Interdiscip Rev Dev Biol 6 doi: 10.1002/wdev.266.

SALÓ, E. (2006). The power of regeneration and the stem-cell kingdom: freshwater planarians (Platyhelminthes). BioEssays 28: 546-559.

SALÓ, E., BAGUÑÀ, J. (1984). Regeneration and pattern formation in planarians. I. The pattern of mitosis in anterior and posterior regeneration in Dugesia(GJtigrina, and a new proposal for blastema formation. J Embryol. Exp Morph 83: 63-80.

SALO, E. BAGUÑÀ, J. (1985). Cell movement in intact and regenerating planarians. Quantitation using chromosomal, nuclear and cytoplasmic markers. J Embryol Exp Morphol 89: 57-70.

SALÓ E, BAGUÑà J (1989). Regeneration and pattern formation in planarians. II. Local origin and role of cell movements in blastema formation. J Embryol Exp Morph 107: 69-76.

SALÓ, E. and BAGUÑ̇̀, J. (2002). Regeneration in planarians and other worms: New findings, new tools, and new perspectives. J Exp Zool 292: 528-39.

SANDMANN, T., VOGG, M.C., OWALAM, S., BOUTROS, M., BARTSCHERER, K. (2011) The head-regeneration transcriptome of the planarian Schmidtea mediterranea. Genome Biol 12: R76. 
SANTABÁRBARA-RUIZ, P., LÓPEZ-SANTILLÁN, M., MARTíNEZ-RODRÍGUEZ, I., BINAGUI-CASAS, A., PÉREZ, L., MILÁN, M., COROMINAS, M., SERRAS, F. (2015). ROS-induced JNK and p38 signaling is required for unpaired cytokine activation during Drosophila regeneration. PLoS Genet 11: e1005595.

SCIMONE, M.L., SRIVASTAVA, M., BELL, G.W., REDDIEN, P.W. (2011). A regulatory program for excretory system regeneration in planarians. Development 138: 4387-4398.

SCIMONE, M.L., LAPAN, S.W., REDDIEN, P.W. (2014a). A forkhead transcription factor is wound-induced at the planarian midline and required for anterior pole regeneration. PLoS Genet 10: e1003999.

SCIMONE, M.L., KRAVARIK, K.M., LAPAN. S.W., REDDIEN, P.W. (2014b). Neoblasts specialization in regeneration of the planarian Schmidtea mediterranea. Stem Cell Reports 3: 339-52.

SCIMONE M.L., COTE L.E., ROGERS T., REDDIEN P.W. (2016). Two FGFRL-Wnt circuits organize the planarian anteroposterior axis. eLife 5: e12845.

SEEBECK, F., MÄRZ, M., MEYER, A.W., REUTER, H., VOGG, M.C., STEHLING, M., MILDNER, K.,ZEUSCHNER, D., RABERT, F., BARTSCHERER, K. (2017). Integrins are required for tissue organization and restriction of neurogenesis in regenerating planarians. Development 144: 795-807.

SHIBATA, N., KASHIMA, M., ISHIKO, T., NISHIMURA, O., ROUHANA, L., MISAKI, K., YONEMURA, S., SAITO, K., SIOMI, H., SIOMI, M.C., AGATA, K. (2016). Inheritance of a nuclear PIWI from pluripotent stem cells by somatic descendants ensures differentiation by silencing transposons in planarian. Dev Cell37:226-237.

SOLANA, J., GAMBERI, C., MIHAYLOVA, Y., GROSSWENDT, S., CHEN, C., LASKO, P., RAJEWSKY, N., ABOOBAKER, A. (2013). The CCR4-NOT complex mediates deadenylation and degradation of stem cell mRNAs and promotes planarian stem cell differentiation. PLoS Genet 9: e1004003.

STÜCKEMANN, T., CLELAND, J.P., WERNER, S., THI-KIM, V.U. H., BAYERSDORF, R., LIU, S.Y., FRIEDRICH, B., JÜLICHER, F., RINK, J.C. (2017). Antagonistic self-organizing patterning systems control maintenance and regeneration of the anteroposterior axis in planarians. Dev Cell 40: 248-263.

SU, H., SUREDA-GÓMEZ, M., RABANEDA-LOMBARTE, N., GELABERT, M., XIE, J., WU, W., ADELL, T. (2017). AC-terminally truncated form of $\beta$-catenin acts as a novel regulator of Wnt/ $\beta$-catenin signaling in planarians. PLoS Genet 13: e1007030.

SUREDA-GÓMEZ, M., MARTÍN-DURÁN, J.M., ADELL, T. (2016). Localization of planarian $\beta$-CATENIN-1 reveals multiple roles during anterior-posterior regeneration and organogenesis. Development 143: 4149-4160.

SUREDA-GÓMEZ, M., PASCUAL-CARRERAS, E., ADELL, T. (2015). Posterior Wnts Have Distinct Roles in Specification and Patterning of the Planarian Posterior Region. Int J Mol Sci 16: 26543-26554.

TANAKA E. (2016). The Molecular and Cellular Choreography of Appendage Regeneration. Cell 165: 1598-1608

TASAKI, J., SHIBATA, N., NISHIMURA, O., ITOMI, K., TABATA, Y., SON, F., SUZUKI, N., ARAKI, R., ABE, M., AGATA, K., UMESONO, Y. (2011). ERK signaling controls blastema cell differentiation during planarian regeneration. Development 138: $2417-2427$.
TU, K.C., PEARSON, B.J., SÁNCHEZ ALVARADO, A. (2012) TORC1 is required to balance cell proliferation and cell death in planarians. Dev Biol 365: 458-469.

TU, K.C., CHENG, L.C., VU, H.T., LANGE, J.J., McKINNEY, S.A., SEIDEL., C.W., SÁNCHEZ-ALVARADO, A. (2015). Egr-5 is a post-mitotic regulator of planarian epidermal differentiation. elife 4: e10501.

UMESONO, Y., WATANABE, K., AGATA, K. (1999). Distinct structural domains in the planarian brain defined by the expression of evolutionarily conserved homeobox genes. Dev Genes Evol 209: 31-39.

VAN WOLFSWINKEL, J.C., WAGNER, D.E., REDDIEN, P.W. (2014). Single-cell analysis reveals functionally distinct classes within the planarian stem cell compartment. Cell Stem Cell 15: 326-39.

VASQUEZ-DOORMAN, C., PETERSEN, C.P. (2014). zic-1 Expression in planarian neoblasts after injury controls anterior pole regeneration. PLoS Genet 10: e1004452

VOGG, M.C., OWLARN, S., PEREZ RICO, Y.A., XIE, J., SUZUKI, Y., GENTILE, L., WU, W., AND BARTSCHERER, K. (2014). Stem cell-dependent formation of a functional anterior regeneration pole in planarians requires Zic and Forkhead transcription factors. Dev Biol 390: 136-148.

VOGG, M.C., WENGER, Y., GALLIOT, B. (2016). How Somatic Adult Tissues Develop Organizer Activity. Curr Top Dev Biol 116: 391-414.

VRIZ, S., REITER, S., GALLIOT, B. (2014). A program to regenerate. Curr Top Dev Biol 108: 121-151.

WAGNER, D.E., WANG, I.E., REDDIEN, P.W. (2011). Clonogenic neoblasts are pluripotent adult stem cells that underlie planarian regeneration. Science 332: 811-6.

WENEMOSER, D., REDDIEN, P.W. (2010). Planarian regeneration involves distinct stem cell responses to wounds and tissue absence. Dev Biol 344: 979-991.

WENEMOSER, D., LAPAN, S.W., WILKINSON A.W., BELL, G.W., REDDIEN, P.W. (2012). A molecular wound response program associated with regeneration initiation in planarians. Genes Dev 26: 988-1002.

WITCHLEY, J.N., MAYER, M., WAGNER, D.E., OWEN, J.H., REDDIEN, P.W. (2013). Muscle cells provide instructions for planarian regeneration. Cell Rep 4: 633-641.

WURTZEL, O., COTE, L. E., POIRIER, A., SATIJA, R., REGEV, A., REDDIEN, P. W. (2015). A Generic and Cell-Type-Specific Wound Response Precedes Regeneration in Planarians. Dev Cell 35: 632-645.

YANGER, K., ZONG, Y., MAGGS, L.R., SHAPIRA, S.N., MADDIPATI, R., AIELLO N.M., THUNG, S.N., WELLS, R.G., GREENBAUM, L.E., STANGER, B.Z. (2013). Robust cellular reprogramming occurs spontaneously during liver regeneration. Genes Dev 27: 719-724.

ZHOU, Q., LI, L., ZHAO, B., GUAN, K. (2015). The Hippo pathway in heart development, regeneration, and diseases. Circ Res 116: 1431-1447.

ZHU, S.J., HALLOWS, S.E., CURRIE, K.W., XU, C., PEARSON, B.J. (2015). A mex3 homolog is required for differentiation during planarian stem cell lineage development. eLife 4: e07025.

ZHU, S.J., PEARSON, B.J. (2016). (Neo)blast from the plast: new insights into plaanrian stem cell lineages. Curr Opin Genet Dev 40: 74-80. 


\section{Further Related Reading, published previously in the Int. J. Dev. Biol.}

Planaria: an animal model that integrates development, regeneration and pharmacology

Oné R. Pagán

Int. J. Dev. Biol. (2017) 61: 519-529 - https://doi.org/10.1387/ijdb.160328op

Stem cells and neural signalling: the case of neoblast recruitment and plasticity in low dose X-ray treated planarians Leonardo Rossi, Paola lacopetti and Alessandra Salvetti

Int. J. Dev. Biol. (2012) 56: 135-142 - https://doi.org/10.1387/ijdb.123505lr

Stem cell protection mechanisms in planarians: the role of some heat shock genes

Maria-Emilia Isolani, Maria Conte, Paolo Deri and Renata Batistoni

Int. J. Dev. Biol. (2012) 56: 127-133 https://doi.org/10.1387/ijdb.113432mi

Heterogeneity of planarian stem cells in the S/G2/M phase

Sören Moritz, Franziska Stöckle, Claudia Ortmeier, Henning Schmitz, Gustavo Rodríguez-Esteban, Göran Key and Luca Gentile Int. J. Dev. Biol. (2012) 56: 117-125 https://doi.org/10.1387/ijdb.113440sm

Comprehensive gene expression analyses in pluripotent stem cells of a planarian, Dugesia japonica

Norito Shibata, Tetsutaro Hayashi, Ryutaro Fukumura, Junsuke Fujii, Tomomi Kudome-Takamatsu, Osamu Nishimura, Syozo Sano, Fuyan Son, Nobuko Suzuki, Ryoko Araki, Masumi Abe and Kiyokazu Agata

Int. J. Dev. Biol. (2012) 56: 93-102 - https://doi.org/10.1387/ijdb.113434ns

Planarian embryology in the era of comparative developmental biology

José M. Martín-Durán, Francisco Monjo and Rafael Romero

Int. J. Dev. Biol. (2012) 56: 39-48 - https://doi.org/10.1387/ijdb.113442jm

Planarian regeneration: a classic topic claiming new attention

Emili Saló and Kiyokazu Agata

Int. J. Dev. Biol. (2012) 56: 1-4 https://doi.org/10.1387/ijdb.123495es

Planarian regeneration: achievements and future directions after 20 years of research. EmiliSaló, Josep F. Abril, TeresaAdell, Francesc Cebrià, Kay Eckelt, Enrique Fernández-Taboada, Mette Handberg-Thorsager, Marta Iglesias, María D. Molina and Gustavo Rodríguez-Esteban Int. J. Dev. Biol. (2009) 53: 1317-132.

5 yr ISI Impact Factor $(2016)=2.421$
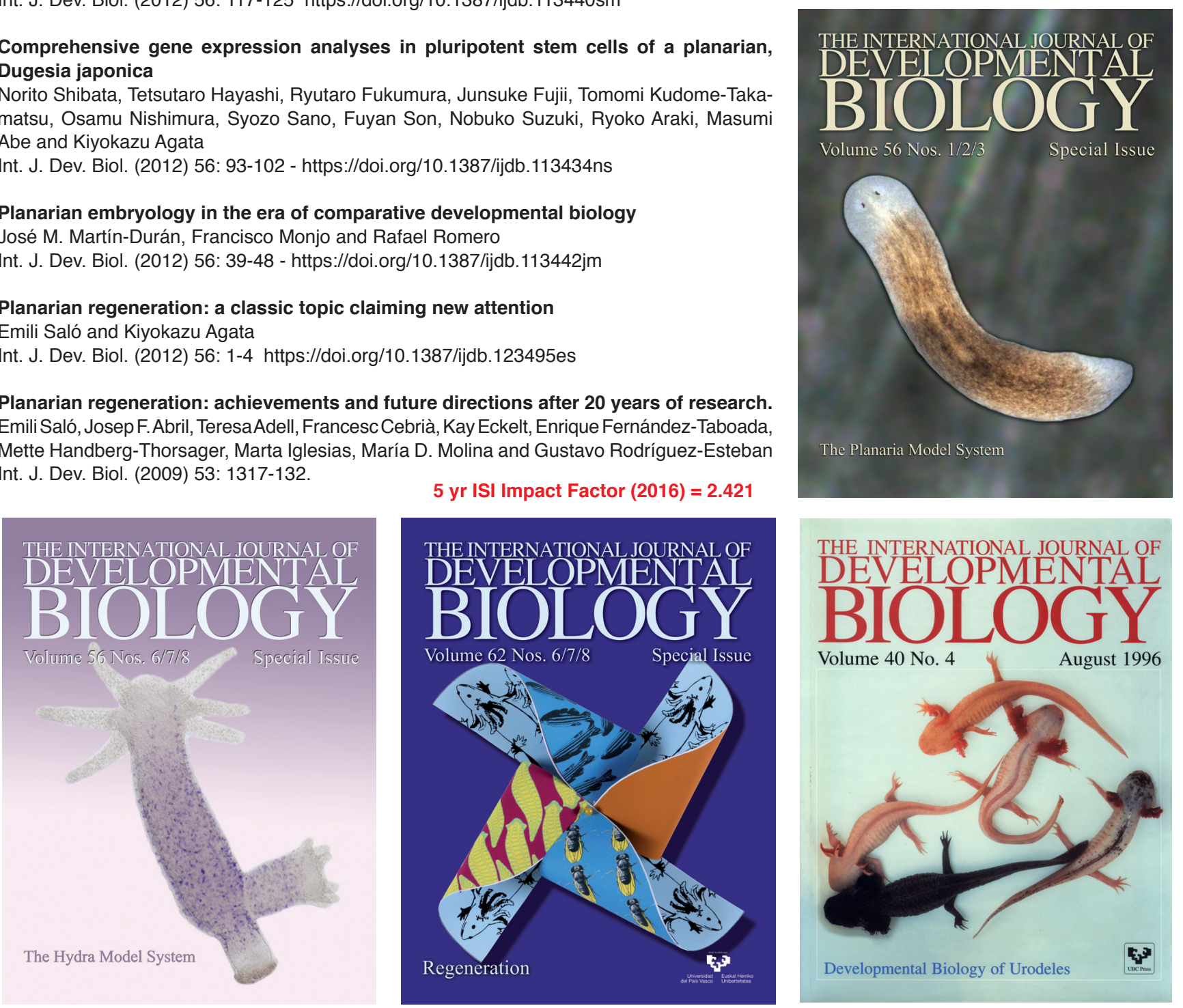